\title{
Mapping the Power Struggles of the National Green Tribunal of India: The Rise and Fall?
}

\author{
Gitanjali Nain GILL* \\ Northumbria University, Newcastle upon Tyne
}

\begin{abstract}
This article documents the life-cycle of the National Green Tribunal of India (NGT). The NGT is officially described as a "specialised body equipped with necessary expertise to handle environmental disputes involving multi-disciplinary issues"- a forum offering greater plurality for environmental justice. Its international and national recognition promotes it as an exemplar for developing nations. The change management theory underpinning the paper is drawn from the work of Kurt Lewin and Edgar Schein, thereby allowing the analysis of competing internal and external forces affecting the NGT. There is a transmigration of theory and its application from one discipline to another social science: business psychology and management to law. The article identifies and addresses the crisis, and analyses the reasons and actions of the principal actors or forces interested in supporting the NGT and, on the other hand, those who are concerned, challenged, and affected by its growth, activities, and popularity.
\end{abstract}

Keywords: National Green Tribunal of India, environmental justice, change management theory, specialized environmental judiciary, India

\section{INTRODUCTION}

What Though the Field Be Lost? All is not Lost. ${ }^{1}$

International declarations and institutions call for judicial specialization, envisaging expert courts and judges and lawyers trained in environmental matters to advance the environmental rule of law and promote sustainable development. ${ }^{2}$ Specialist environment courts and tribunals are better positioned than general courts to develop innovative remedies and holistic solutions to environmental problems by embracing a flexible mechanism for dispute

\footnotetext{
* Professor of Environmental Law, Northumbria University, Newcastle upon Tyne, UK. Correspondence to Gitanjali Nain Gill, Faculty of Business and Law, Northumbria Law School, Northumbria University, Newcastle upon Tyne, UK. E-mail address: gita.gill@northumbria.ac.uk. The author thanks Emeritus Professor Philip A. Thomas, Cardiff Law School (UK), as well as the anonymous referees for their constructive comments and Tejeshwar S. Gill for his technical assistance.

1. Milton (1667), L. 105.

2. Johannesburg Principles (2002); London Bridge Statement (2002); Rome Symposium (2003); Bhurban Declaration (2012); Asian Development Bank (2012); Asian Development Bank (2015); United Nations Environment Programme (2005); United Nations Environment Programme (2015).
} 
resolution. ${ }^{3}$ In this context, India's commitment to a "green court" assumes significant practical importance. The National Green Tribunal of India (NGT) was established by statute in $2010 .{ }^{4}$ Subsequently, the NGT acquired a national and international reputation based upon its progressive, innovative environmental decisions that reach far beyond the courtroom door. The judicial membership of the NGT comprises legal and scientific experts-a composition unique within India. It has resulted in a symbiotic, dynamic community of decisionmakers employing a vigorous, flexible court process that offers swift, affordable, and open public access through the widest possible interpretation of who is an aggrieved party.

The widespread recognition of this bold, innovative tribunal is fulsome and positive. It stands as an exemplar for developing nations. Pring and Pring describe the NGT in their path-breaking publication on courts and environmental tribunals as "incorporating a number of best practices ... and has become a major arbiter of some of the most pivotal environmental battles in India." They subsequently stated "the NGT has successfully expanded its openness, procedural flexibility, transparency and progressive judgments." ${ }^{\prime 6}$ Lord Carnwath of Notting Hill, Judge of the Supreme Court UK, observed the tribunal as "raising awareness and a sense of environmental responsibility in the government, local and national, and the public." "7 Chief Justice Brian Preston, Land and Environment Court of NSW Australia, wrote "the NGT is an example of a specialized court to better achieve the goals of ensuring access to justice, upholding the rule of law and promoting good governance." 8 Judge Michael Hantke Domas, Chief Justice of the Third Environmental Court Chile, focused on the novelty and boldness of the NGT. According to Domas J., "as a new player in the Indian judicial panorama, the NGT was strongly led by knowledgeable and valorous judges, who were fit to answer justice demands of the people represented by equally qualified and tenacious lawyers." " Judge Michael Rackemann of the Queensland Planning and Environmental Court considered "the NGT adopts a robust and expansionist approach to the interpretation of its jurisdiction and powers." 10 Academic experts including Warnock described the NGT as follows: "the NGT is one of the world's most progressive Tribunals ... the procedures adopted, powers assumed, and remedies employed by the NGT are notable." ${ }^{11}$ Ryall stated:

the emergence of the NGT, its contemporary jurisprudence and impact on Indian society provide important insights for anyone interested in environmental governance and regulation ... the NGT is held in high esteem and enjoys a strong degree of public confidence. ${ }^{12}$

Similar views have been expressed in India. The Vice President of India, M. Venkaiah Naidu, applauded the tribunal by stating "the efforts and involvement of the NGT in dispensation of environmental justice, evolving environmental jurisprudence, promoting discourse and spreading awareness are commendable ... all stakeholders stand united and

\footnotetext{
3. Preston (2012), p. 398.

4. The NGT Act 2010.

5. Pring \& Pring (2016), pp. 34-5.

6. Ibid.

7. Carnwath (2017).

8. Correspondence with the author dated 29 May 2018.

9. Domas (2017), p. 560.

10. Rackemann (2017), p. 473.

11. Warnock (2017), p. 210.

12. Ryall (2017), p. 3.
} 
miss no opportunity to join hands for the same."13 Prakash Javadekar, Minister for Human Resource Development, in a similar vein stated "the NGT has been responsible for expeditious dispensation of environmental justice in our country, thus, satisfying legislative intent behind its enactment." 14 Judge Rajan Gogoi of the Supreme Court of India observed "Its [NGT] advent marks another rendition of India's green revolution ... with the passage of time the NGT has become one of the foremost environmental courts globally with a wide and comprehensive jurisdiction." 15 Ritwick Dutta, a leading environmental barrister, stated "the Green Tribunal is now the epicentre of the environmental movement in India .... It has become the first and last recourse for people." ${ }^{16}$ Fieldwork undertaken at the NGT involving interviews with lawyers and litigants appearing before the tribunal reinforce the professional and public assessment of the value and appreciation of the strength of the NGT. ${ }^{17}$ A young lawyer who appears before the NGT described it: "a bench of this kind with an expert member is creating new environmental jurisprudence. The expert members help young lawyers understand environmental issues." 18 Three litigants summarized their experiences before the NGT as "our experience has been tremendous in the NGT benches. We are attending the case in person and have been here three to five times. The NGT is a life saver. The NGT has given us justice." 19

Nevertheless, these national and international commendations of the NGT tell but part of the story of the tribunal. The tribunal has been subject to criticism at the national level from key affected parties. For instance, "officials speak about the Tribunal's clamour to get more powers and perks. They call it a 'power-hungry institution' that has failed the purpose for which it was created." 20 The NGT has been accused of overstepping its jurisdiction by not following the provisions of the NGT Act 2010, resulting in embarrassment to the government before Parliament. ${ }^{21}$ Again, the NGT's orders have been considered as a case of judicial overreach, as they disturb the balance of power between the judiciary and the executive as envisaged in the Indian constitutional structure. For example, the NGT's general order banning mining of sand without a requisite environmental clearance from the State Environment Impact Assessment Authority was considered as a case of judicial overreach by Manohar Parrikar, the Goa Chief Minister. According to Parrikar:

the order is a case of (judicial) overreach. Everyone knows the order is not implemented. It (the order) has resulted in rise of prices and black marketing of sand .... If you stop economic activity, we (Governments) will not have money to pay. We might also have to take a cut (from the illegal sand mining operation) .... Irrational and sudden bans order going across board should not be issued without hearing the State. ${ }^{22}$

\footnotetext{
13. Naidu (2017).

14. Javadekar (2017).

15. Gogoi (2017).

16. Dutta (2015).

17. Gill (2017).

18. Ibid., p. 155.

19. Ibid., p. 156.

20. Chowdhary (2014).

21. Anand (2013).

22. Mayabushan (2013).
} 
Similarly, the ministers and officials from the states of Arunachal Pradesh, Mizoram, and Manipur were of the view that sand-mining orders without prior clearance from the environment ministry across India was a case of not studying the situation in the north-eastern states. $^{23}$

There have emerged negative forces within India determined to contain or possibly close the tribunal. This is an account of two campaigns-one seeking to promote the NGT, the other constituting a restraining force. This article comprises four sections. It opened with a brief account of the current standing of the NGT in judicial and academic international and national communities. The second section presents the paper's theoretical underpinning derived from social psychology and organizational management scholarship. It offers a practice-based, theoretical framework applicable to the NGT. The article employs a transmigration of theory and its application from one discipline to another social science: business psychology and management to law. In the third section, the history of the NGT is unpacked by identifying the principal actors or forces, both positive and negative, involved in the establishment, exercise, and review of the tribunal. Today, the NGT faces major challenges regarding its future survival because of external "restraining forces" seeking to downgrade its status and functionality. This section addresses this crisis, identifies and analyses the reasons and actions of those interested in supporting the NGT and, on the other hand, those who are concerned and challenged by its growth, activities, and popularity. This growing lobby constitutes a negative force seeking to restraint and even possibly close the NGT. This oppositional struggle process commenced in 2011 and continues to date. The conclusion reviews the relationship between theory and practice as played out in the life history of the NGT.

\section{THEORETICAL FRAMEWORK: THREE-STEP CHANGE MODEL AND FORCE-FIELD THEORY}

Kurt Lewin (1890-1947) is considered an influential physicist and psychologist and, for the purposes of this paper, the founding father of change management theory. ${ }^{24}$ Lewin's work on planned change $\mathrm{e}^{25}$ provides an elaborate and robust approach to understanding and resolving social conflict, whether in an organization or wider society. As Edgar Schein commented:

The intellectual father of planned change is Kurt Lewin. His seminal work on leadership style and the experiments on planned change that sought to understand and change consumer behaviour launched a generation of research in group dynamics and the implementation of change programmes. ${ }^{26}$

The relevance of Lewin's work to fast-changing modern organizations continues to this day. Change management is defined as "the process of continually renewing an organization's direction, structure, and capabilities to serve the ever-changing needs of external and internal

23. Shrivastava \& Shrivastava (2015), p. 173.

24. Burnes \& Cooke (2013), p. 408; Cummings et al. (2016), p. 34.

25. The planned change approach encompasses separate themes of work: field-force theory, group dynamics, action research, and a three-step model of change. These were considered by Lewin and coalesced into four mutually reinforcing themes to analyze and bring effective change.

26. Schein (1988), p. 239. 
customers. ${ }^{27}$ The academic literature on organizational change reflects consensus on two important matters. First, the pace of change is faster in the present economic and globalized environment. $^{28}$ Second, internal and external factors precipitate change and affect organizations. ${ }^{29}$ Thus, change is "both pervasive and persistent and normality" ${ }^{\text {, }}$ but simultaneously "reactive, discontinuous, ad hoc and often triggered by a situation of organisational crisis." 31

Understanding organizational change requires an analysis of the "field as a whole,"32 as it helps to analyze scientifically the pattern of forces operating in the group. "The process is but the epiphenomenon, the real object of the study is the constellation of forces." ${ }^{33}$ In this context, Lewin's "three-step change model" and "field-force theory" are of foundational importance. There exists a body of lively, disparate opinion and literature about Lewin's diluted and overly simplistic theories that are beyond the scope of this article. ${ }^{34}$ For instance, Kanter claims that "Lewin's ... quaintly linear and static conception-the organisation as an ice cube-is so wildly inappropriate that it is difficult to see why it has not only survived but prospered." ${ }^{35}$ Nevertheless, Lewin's contribution remains the quintessence of organizational change. It explores, assesses, and creates organizational realities to address and answer issues about resistance, barriers, and failure to change initiatives. ${ }^{36}$

\subsection{The Three-Step Change Model}

Lewin's "three-step change model" is considered as the bedrock of organizational change. Successful change according to Lewin includes three aspects: "unfreezing the present level ... moving to the new level ... and freezing group life on the new level."37

Lewin also suggested that change at any level is determined by a force field thereby facilitating the movement of the organization to a new level of equilibrium.

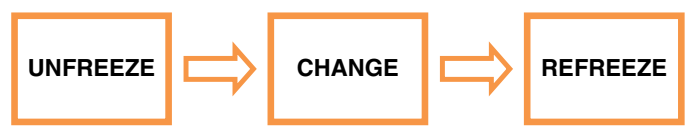

Figure 1. Kurt Lewin change model. Source: Lewin (1947); Schein (2010)

27. Moran \& Brightman (2001), p. 111.

28. Balogun \& Hailey (2004), p. 3; Graetz (2000), p. 550; Burnes (2009), p. 1; Kotter (2007), p. 2; Carnall (2003), p. 3; Hussain et al. (2017), p. 2.

29. Kotter, supra note 28, pp. 5-6; Luecke (2003), pp. 3-5; Pierce et al. (2002), p. 628.

30. Hammer \& Champy (1993), p. 23.

31. By (2005), p. 370.

32. Lewin (1997), p. 291.

33. Ibid.

34. Cummings et al., supra note 24; Clegg et al. (2005), p. 376; Child (2005), p. 293; Rummel (1975), p. 41; Hustedde \& Score (1995), p. 3; Burnes \& Cooke, supra note 24, p. 421; Gulati (2007), p. 775; Tsoukas \& Chia (2002), p. 570; Marshak \& Heracleous (2004), p. 1051.

35. Kanter et al. (1992), p. 10.

36. Burnes \& Cooke, supra note 24.

37. Lewin, supra note 32 , p. 330. 
Lewin's basic paradigm (unfreeze-change-freeze) was elaborated and refined by Schein for a better understanding of the psychosocial dynamics of transformative organizational change. ${ }^{38}$ In his 2010 work, Schein observed that the process of change entails creating the perception that the change is needed, then moving towards learning new concepts, and finally institutionalizing new concepts as a norm. ${ }^{39}$

Accordingly, the first step is "unfreezing or creating a motivation to change. This requires the 'group' that is the target of change must unlearn something." ${ }^{40}$ Unfreezing involves three processes to develop motivation to change: (1) disconfirming data creating disequilibrium due to the organization's inability to achieve its goals or its processes, thereby pointing out that "something is wrong somewhere" 41 ; (2) making the members of organization uncomfortable and anxious, implying "unless we change, something bad will happen to the individual, the group, and/or the organization" ${ }^{42}$; and (3) psychological safety, in the sense of being able to see "the problem and learning something new"43 by adopting a positive vision, team effort, and constructive support.

The second step is "cognitive redefinition" that lays the groundwork for making the change. Learning new concepts, expanding concepts with broader meaning and new standards of evaluation either through "imitating a role model ... or scan our own environment and develop our own solutions," 44 thereby moving to a new changed state. The mechanism works best when there is clarity about the goals to achieve and the new way of working.

The final step is "refreezing" wherein the new learning is reinforced and institutionalized for producing better confirmed actual results to fix the problems that launched the change programme. ${ }^{45}$ The change has been made and the emphasis is on structures and procedures that help to maintain the changed behaviour in the system. Thus, to maintain the new change as permanent, institutional policies and procedures should encourage and reinforce the new behaviour until it becomes a habit.

The "three-step change model" (classic model) has become "far more fundamental and instrumental than Lewin ever intended ... a solid foundation ... hardened through series of interpretations ... repress[ing] other ways of seeing or organising thinking about change."46 Lewin's classic model has continuing relevance to contemporary organizations. Its application to an adjudicatory body such as the NGT is useful in understanding this new organizational reality - the NGT that seeks to promote sustainable development.

\subsection{Force-Field Theory}

Lewin's pioneering work on force-field theory is often considered as the epitome of a change model providing the "theoretical underpinning of all his applied work." 47 Field theory,

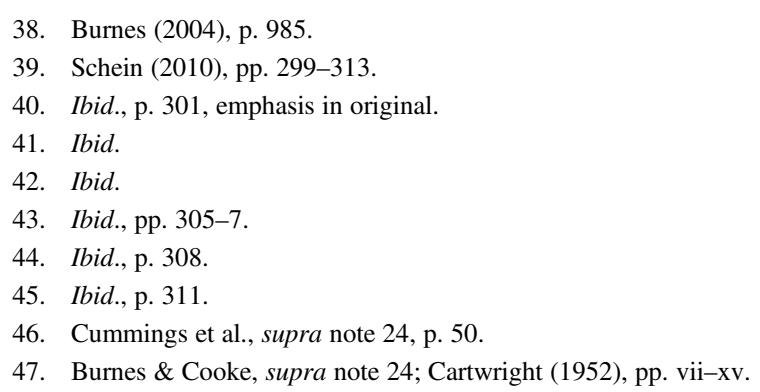


through its scientific rigour and practical relevance, analyzes the changing behaviour of individuals through the operation of forces in life. As stated above, the force-field theory integrates with the classic model to bring about planned change at the individual, group, organization, or societal level. ${ }^{48}$

According to Lewin, "change and constancy are relative concepts; group life is never without change, merely differences in the amount and type of change exist." 49 The construct "force" characterized the direction and strength of tendency to change. He believed that the driving and "restraining forces" tend to cause the changes. The forces towards a positive side are the "driving forces," whereas the "restraining forces" create physical or social obstacles:

"Driving forces"- corresponding, for instance, to ambition, goals, needs, or fears—are "forces towards" something ... tend to bring a change ... a "restraining force" is not in itself equivalent to a tendency to change; it merely opposes "driving forces." 50

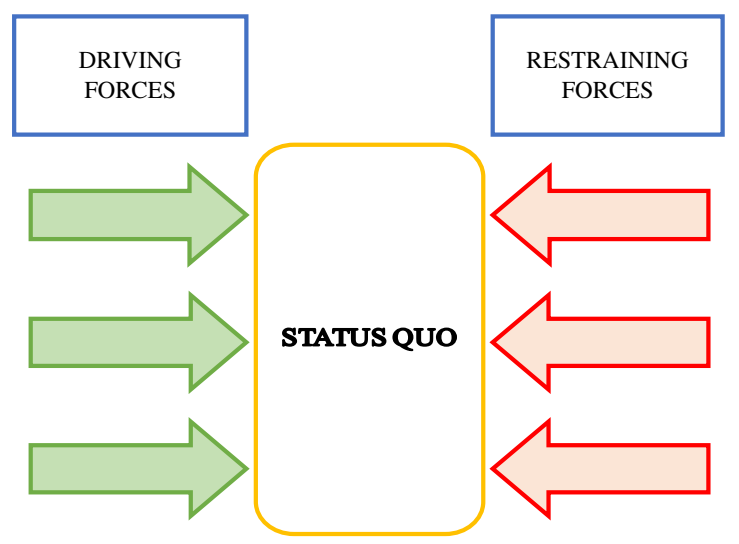

Figure 2. Kurt Lewin force-field analysis.Source: Lewin (1943)

Where the forces are equal in magnitude, the status quo will be maintained. ${ }^{51}$ However, "quasi-stationary equilibria can be changed by adding forces in the desired direction or diminishing opposing forces." ${ }^{, 52}$ Lewin recognized that forces shift quickly and radically under certain circumstances such as organizational or societal crisis, and thus lead to the loss of the status quo. "New patterns of activity can rapidly emerge, and a new behavioural equilibrium or 'quasi-stationary equilibrium' is formed.",53

To understand the actual changes and its effect, it is important to examine the total circumstances and not merely one property. According to Lewin:

\footnotetext{
48. Burnes, supra note 38, p. 981.

49. Lewin, supra note 32, p. 307.

50. Ibid., p. 322.

51. Lewin (1943), p. 172.

52. Ibid., p. 320.

53. Lewin (1947), p. 199; Kippenberger (1998), pp. 10-12.
} 
to change the level of velocity of a river its bed has to be narrowed or widened, rectified, cleared from rocks etc. ... for changing a social equilibrium, too, one has to consider the total social field: the groups and subgroups involved, their relations, their value system etc. ${ }^{54}$

To achieve successful change, the "driving forces" must always outweigh "restraining forces." This provides support in moving through the unfreezing-learning-refreezing stages of change. For Lewin, the change was a slow learning process, the success of which depended on how individuals or groups understood and reflected on the forces that impinged on their lives. ${ }^{55}$

The use of force-field theory is helpful to understand the change analysis insights that align with the current organizational environment of the NGT. The interplay of forces would help distinguish whether factors within and without the NGT are "driving forces" for change or "restraining forces" that work against desired change.

\section{APPLICATION OF THEORY: THE NATIONAL GREEN TRIBUNAL}

This section deals with the practical application of Kurt Lewin's theory followed by Schein's work that developed the three-step change model. The framework has been applied to various organizations, including the NHS, ${ }^{56}$ the poor state of primary education in the state of Bihar, India, ${ }^{57}$ gender, ${ }^{58}$ and IT implementation. ${ }^{59}$ However, this is the first time it has been applied to an Indian adjudicatory tribunal: the NGT.

In Lewin's theory, the existence of an "organization" is central to understanding change. Academics have defined the term "organization" from different perspectives. These include adopting a professional categorization, as human labour, conscious human activity linking and co-ordinating all the production agents to achieve the optimum result of the work, or a scientific approach. ${ }^{60}$ A definition by McGovern suggests that an organization is "an organised or cohesive group of people working together to achieve commonly agreed goals and objectives."61 Adopting McGovern's definition, it is advanced here that the courts and tribunals are organizations within the "new public management (NPM)" paradigm. ${ }^{62}$ The focus of NPM is on "quality," namely "achieving the full potential that one is capable of with the resources one has" ${ }^{23}$ with a "client-oriented approach." 64 In the context of judicial organizations, "quality" in NPM includes the principles of effectiveness, efficiency, and

\footnotetext{
54. Lewin, supra note 32, p. 327.

55. Burnes \& Cooke, supra note 24, p. 413.

56. Baulcomb (2003), pp. 275-80.

57. PLA Notes (1999), pp. 17-23.

58. Lan \& Lee (1997), pp. 43-52.

59. Bozak (2003), pp. 80-5.

60. Allen \& Sawhey (2018), pp. 4-6; Ivanko (2013), pp. 1-3; Ahmady et al. (2016), pp. 456-7.

61. Allen \& Sawhey, supra note 60, p. 4.

62. $\mathrm{Ng}$ (2007), p. 11; Van d. Walle \& Hammerschmid (2011), p. 191. This article does not address the debate about the nature of the NPM. The considerable scepticism about the consistency of the NPM has generated a body of lively and disparate opinion and literature beyond the scope of this article. For details, see Barzelay (2002), p. 15; Lynn Jr (1998); Pollitt (1995); Christensen et al. (2008); Brunsson (1989).

63. Ng, supra note 62 , p. 29.

64. Ibid., pp. 11-12.
} 
transparency. ${ }^{65}$ Factors including time, timeliness, competency, consistency, accessibility, accuracy, and responsiveness provide direction and help in assessing quality service in the judicial organization. ${ }^{66}$ The fulfilment of quality requirements contributes towards the legitimization of judicial organizations towards the public and are compatible with values such as equity and equality. ${ }^{67}$

The courts and tribunals in India are judicial organizations that guarantee the "quality" requirements for the effective delivery of justice. Specifically, the NGT is an "organization" consisting of legal and scientific experts who create a symbiotic relationship that operates collectively as joint decision-makers and adjudicators to dispense environmental justice. The overarching goal is contained in the Preamble of the NGT Act 2010. It aims for the effective and expeditious disposal of cases relating to environmental protection, conservation of forests and other natural resources, including enforcement of environmental legal rights, giving relief and compensation for damages to persons and property, and for matters connected or incidental. The NPM “quality" principles are reflected in the NGT's measurable characteristics: participatory parity by giving a liberal and flexible interpretation in terms of "aggrieved party" (standing) to access environmental justice ${ }^{68}$; the availability of "resources to enable participation" through low fees ${ }^{69}$; the ability both to fast-track and decide cases within six months of application or appeal ${ }^{70}$; and application of the sustainable development, precautionary, and polluter-pays principles when passing any order, decision, or award for effective implementation of environmental rights and duties in India. ${ }^{71}$

In this context, I apply Lewin's model of organizational change to the NGT. Comprehending the kinetics of Lewin's force-field theory is vital in learning to apply his "three-step change" in practical situations.

65. Mak (2008), p. 735. Mak argues that the NPM paradigm influences the European judicial organization to solve questions in a liberal democracy. The legitimacy of the judicial organization on the European level is dependent on the realization of a balance of principles that is supported by the European legal order and society.

66. Petrick \& Lindsay (1996), p. 55.

67. Mak, supra note 65 , pp. $725-6$.

68. Section 18(2) NGT Act 2010 states "an application for grant of relief, or compensation or settlement of a dispute may be made to the Tribunal by a person who has sustained an injury; is the owner of the property to which damage has been caused; is the legal representative in the case of death resulting from environmental damage; is a duly authorised agent; represents a state agency; or is an aggrieved person, including any representative body or organisation." Participatory parity has been addressed in the NGT by providing an expansive interpretation of the term "aggrieved person." 69. The NGT (Practices and Procedure) Rules 2011, Rule 12(2), provides for an application or appeal where no compensation has been claimed to be accompanied by a fee of INR 1,000 (GBP 10).

70. Section 18(3) states "the application, or as the case may be, the appeal filed before the Tribunal under this Act shall be dealt with by it as expeditiously as possible and endeavour shall be made by it to dispose of the application, or, as the case may be, the appeal, finally within six months from the date of filing of the application, or as the case may be, the appeal, after providing the parties concerned an opportunity to be heard."

71. Section 20 provides "the Tribunal shall, while passing any order or decision or award, apply the principles of sustainable development, the precautionary principle and the polluter pays principle." See Gram Panchayat Totu Majthai v. State of Himachal Pradesh, Judgment, 11 October 2011; Durga Dutt v. State of Himachal Pradesh, Judgment, 6 February 2014; Jal Biradari v. MoEF, Judgment, 22 January 2015; Vitthal Gopichand Bhungase v. Gangakhed Sugar and Energy Ltd, Judgment, 30 July 2014; Forward Foundation v. State of Karnataka, Judgment, 7 May 2015; Ramdas Janardan Koli v. Secretary, MoEF, Judgment, 27 February 2015; Leo Saldhana v. Union of India, Judgment, 27 August 2014. 


\subsection{Unfreeze}

Unfreezing the old behaviour to learn something new provides motivation to change. The focus is to address underlying problems and initiate diagnostic work to accept new learning and reject old or dysfunctional behaviour.

The unfreezing was triggered by strong "driving forces," being the Supreme Court of India and the Indian Law Commission. They identified problems and challenges relating to environmental adjudication and dispensation of environmental justice in India. The perceived accepted need within these institutions to "unlearn and learn something new" was powerful.

The Supreme Court of India was the initial primary external driving force behind the initial unfreezing or motivation-to-change process. The Supreme Court's intervention was based on its twofold concern. First was the complexity and uncertainty underpinning the scientific environmental evidence presented in court. The Supreme Court was conscious that complete scientific certainty is the exception, not the norm. Uncertainty, resulting from inadequate data, ignorance, and indeterminacy, is inherent in science. ${ }^{72}$ The court was aware of the scientific limitations of the judiciary in environmental cases where science should undertake a key function. The involvement of independent qualified scientists sitting as equals with judicial members would go some way to ameliorating the above concerns. Second, there is an ossified litigious legal system that challenges and possibly surpasses the court delays described in Jardine v. Jardine in Dickens's Bleak House. Delay is not a recent phenomenon and can be traced back to the time of the Raj. It is a result of court clogging, adjournments, missing papers, absent witnesses, and conscious delaying tactics by both lawyers and the parties. ${ }^{73}$

In M. C. Mehta v. Union of India, ${ }^{74}$ the Supreme Court advocated the establishment of environmental courts, stating:

we would also suggest to the Government of India that since cases involving issues of environmental pollution, ecological destruction and conflicts over national resources are increasingly coming up for adjudication and these cases involve assessment and evolution of scientific and technical data, it might be desirable to set up environment courts on a regional basis with one professional judge and two experts, keeping in view the expertise required for such adjudication. There would be a right to appeal to this court from the decision of the environment court. ${ }^{75}$

The proposal to establish environmental courts was supported by two subsequent cases: Indian Council for Enviro- Legal Action v. Union of India ${ }^{76}$ and AP Pollution Control Board v. M. V. Nayudu. ${ }^{77}$ The court suggested an environmental court would benefit from the expert advice of environmental scientists and technically qualified persons as part of the judicial process. There was a further recommendation that the Law Commission of India should examine the matter of establishing an environmental court.

In the Indian Council for Enviro-Legal Action case, ${ }^{78}$ the Supreme Court highlighted the issue of delay. Cases are lodged within a system already groaning under the weight of its

72. Gill (2016), pp. 178-9.

73. Moog (1992), pp. 19-36.

74. M. C. Mehta v. Union of India (1986) 2 SCC 176.

75. Ibid., p. 202.

76. Indian Council for Enviro-Legal Action v. Union of India (1986) 3 SCC 212.

77. AP Pollution Control Board v. M. V. Nayudu (1999) 2 SCC 718; (2001) 2 SCC 62. The first Nayudu case was in 1999 and the second Nayudu case was in 2001.

78. Indian Council for Enviro-Legal Action v. Union of India (1986), supra note 76. 
case-load. The court, aware of the existence of other specialized tribunals, for example in consumer-protection law, seized the opportunity to highlight the importance of specialized environmental courts, stating:

The suggestion for the establishment of environment courts is a commendable one. The experience shows that the prosecutions launched in ordinary criminal courts under the provisions of Water Act, Air Act and Environment Act never reach their conclusion either because of the workload in those courts or because there is no proper appreciation of the significance of the environment matters on the part of those in charge of conducting those cases. Moreover, any orders passed by the authorities under Water, Air or Environment Acts are immediately questioned by the industries in courts. Those proceedings take years and years to reach conclusion. Very often, interim orders are granted meanwhile which effectively disable the authorities from ensuring the implementation of their orders. All these point to the need for creating environment courts which alone should be empowered to deal with all matters, civil and criminal, relating to the environment. ${ }^{79}$

The interventions and dicta by the Supreme Court during this period were also influenced by the non-implementation and non-operation of two statutes that supported the creation of a specialized environmental tribunal. These were the National Environment Tribunal (NET) Act 1995 and the National Environmental Appellate Authority (NEAA) Act 1997.

The NET Act 1995 provided strict liability for damages arising out of any accident occurring while handling any hazardous substance and for the establishment of a tribunal for effective and expeditious disposal of cases arising from such accidents with a view to giving relief and compensation for damages to person, property, and the environment. The composition of the tribunal consisted of a chairperson with membership including vice-chairpersons, judicial members, and technical members as the central government deemed fit. Unfortunately, it was not notified "due to the sheer neglect and/or lack of political will to take the risk on the part of the executive to pave the way for the establishment of such a specialized environment Tribunal." 80 The environment tribunal was not constituted.

Subsequently, the NEAA Act 1997 provided for the establishment of the NEAA to hear appeals with respect to restriction of areas in which any industries, operations, or processes shall be carried out or not subject to safeguards under the Environmental (Protection) Act 1986. Expertise or experience in administrative, legal, management, or technical aspects of problems relating to environmental management law, planning, and development were essential qualifications for persons to be appointed to the NEAA. The NEAA was established on 9 April 1997 to address grievances regarding the process of environmental clearance and implement the precautionary and polluter-pays principles. ${ }^{81}$ However, the NEAA did little work because its role was limited to the examination of complaints regarding environmental clearances. After the first chairperson's term expired, no replacement appointment was made. ${ }^{82}$ In Vimal Bhai v. Union of India High Court of Delhi, ${ }^{83}$ the court expressed concern that the government was unable to find qualified members to fill positions in the NEAA. The posts of chairperson and vice-chairperson remained vacant from July 2000 until the 1997 Act

79. Ibid., p. 252.

80. Desai \& Sandhu (2010), p. 103.

81. For a detailed discussion, see AP Pollution Control Board v. M. V. Nayudu, supra note 77.

82. Desai \& Sandhu, supra note 80, p. 104.

83. Vimal Bhai v. Union of India High Court of Delhi, CM 15895/2005 in WP(C) 17682/2005. 
was repealed by the National Green Tribunal (NGT) Act $2010 .{ }^{84}$ Thus, the NEAA was closed.

Following the powerful observations made by the Supreme Court, the Law Commission, an active and influential participant in legal reform in India, became a strong organizational driving force to motivate change through the establishment of "environment courts." 85 The Law Commission examined the questions by reviewing the technical and scientific problems that arise before courts and observed:

it is clear that the opinions as to science which may be placed before the Court keep the judge always guessing whether to accept the fears expressed by an affected party or to accept the assurances given by a polluter. ${ }^{86}$

The Law Commission was persuaded that, in seeking a balanced, informed decision in such cases, "environmental courts" with scientific as well as legal inputs would be better placed to reach a determination. Such courts could have wide powers to make on-the-spot inspections and hear oral evidence from resident panels of environmental scientists. In addition, it was suggested that the establishment of environmental courts would reduce the burden on the High Courts and Supreme Court, often involving complex and technical environmental issues, thereby providing accessible and speedy justice. ${ }^{87}$

At that time, the weaker "restraining force" to the Supreme Court and Law Commission of India was the Government of India. The government proposed a centralized Appellate Authority based in Delhi to hear appeals over the statutory authority, namely the Water Act, 1974, the Air Act, 1981, and the Environment (Protection) Act, $1986 .{ }^{88}$ The proposal did not contain provisions for technical or scientific inputs in the centralized Appellate Authority. Figure 3 illustrates the effect of field-forces regarding the NGT.

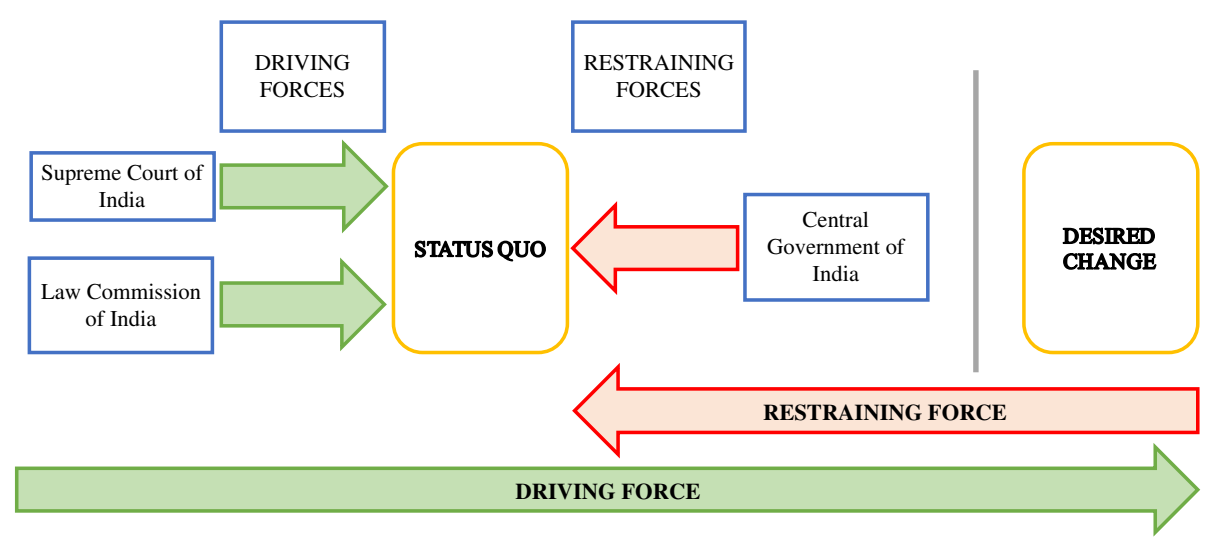

Figure 3. Initial dominant driving forces. Source: Author

84. NGT Act 2010, s. 38(1) (repealing the NET Act 1995).

85. Law Commission of India (2003), p. 142.

86. Ibid., p. 13 .

87. Ibid., p. 21.

88. Ibid., p. 3. 
Initially, the "driving forces" outweighed the "restraining forces," thereby triggering a change from the present level to the desired one. Thus, the first step of "unfreezing" witnessed the "driving forces" advocating a change that would shape the future of environmental justice in India.

\subsection{New Learning and Change}

After an organization is unfrozen, the forces effect a change that reflects "new learning" and moving to a new state. For Lewin, the term learning "refers [ed] in a more or less vague way to some kind of betterment ... and a multitude of different phenomenon." 89 In an organizational set-up, "new learning" reflects "cognitive redefinition" comprising (1) learning new concepts; (2) learning new meaning for old concepts; and (3) adopting new standards of evaluation. ${ }^{90}$ The two mechanisms that help "new learning" are either through imitation and identification with a role model or scanning the environment. ${ }^{91}$ Imitation and identification work best when there is clarity about the new concept and way of working. Scanning the environment works through trial and error and developing own solutions until something works. ${ }^{92}$

\subsubsection{Learning New Concepts}

In India, the "new learning" stage witnessed the involvement of both the external and internal "driving forces" influenced by the societal needs, values, and hopes, and the long-term development of Indian environmental justice discourse. The specialized NGT as a learning new concept following the strong judicial pronouncements and recommendations of the powerful Law Commission of India was the first step towards "new learning."93

The NGT as a specialized body equipped with necessary expertise to handle environmental disputes involving multidisciplinary issues became a forum offering greater plurality for environmental justice. As a learning new concept, it was guided by imitation and identification with a role-model mechanism that embraced the need for specialized tribunals with technical expertise to provide environmental justice.

The external "driving forces" to introduce "change" were first triggered by the Ministry of Environment and Forests (MoEF). ${ }^{94}$ It is important to note that the MoEF acted as a driving force between 2009 and 2011. After 2011, it became a strong restraining force. The reason for this reversal was the replacement of the progressive Minister for MoEF (see Figure 4).

89. Lewin, supra note 32, p. 215.

90. Schein, supra note 39, pp. 308-10.

91. Ibid., p. 310.

92. Ibid.

93. According to the Business dictionary, concept has been defined as "a clear, detailed description of the attributes and benefits of a new product that addresses the needs of the targeted customers" (http://www.businessdictionary.com/ definition/concept.html). The concept of tribunals in India has become an essential part and plays an effective role in the justice-delivery system. A tribunal may be termed as a court if it has all the trappings of a court and satisfies the essential parameters. Every court may be a tribunal but every tribunal necessarily may not be a court. Tribunals are the quasijudicial bodies established to adjudicate disputes related to specified matters that exercise the jurisdiction according to the statute establishing them. The tribunals emerged not with the sole promise of speedy, effective, decentralized dispensation of justice, but also with the expertise and knowledge in specialized areas that were felt to be lacking in the judges of traditional courts. For details, see Law Commission of India (2017), pp. 4, 5, 32. See also Virindar Kumar Satyawadi v. State of Punjab AIR 1956 SC 153; Associated Cement Co. Ltd. v. P.N. Sharma AIR 1965 SC 1595; Kihoto Hollohon v. Sri Zachilhu AIR 1993 SC 412; State of Gujarat v. Gujarat Revenue Tribunal Bar Association (2012) 10 SCC 353.

94. In 2014, the MoEF was renamed as the Ministry of Environment, Forests and Climate Change (MoEFCC). For the purpose of clarity and consistency, the term MoEF is used throughout this article. 


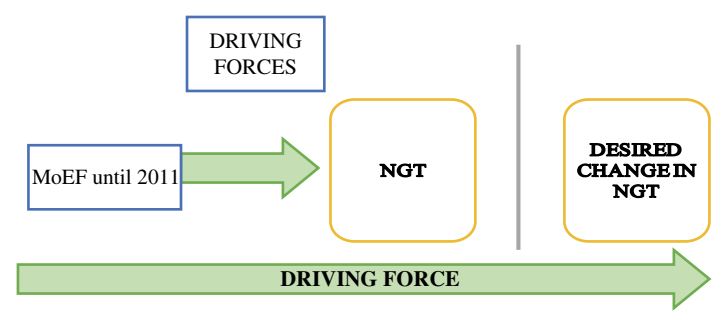

Figure 4. MoEF as a driving force (2009-11). Source: Author

The Government of India through the MoEF introduced the NGT Bill 2009 in the Lower House (Lok Sabha) of the Indian Parliament on 31 July 2009. ${ }^{95}$ According to the then environment minister, Jairam Ramesh, the tribunal was "one element" of a reformist approach to environmental governance. To quote the minister from the parliamentary debate:

Environment is becoming increasingly an interdisciplinary scientific issue ... the fact of the matter is that we need judicial members because there are matters of law involved; and we need technical members who can provide scientific and technical inputs .... There are 5,600 cases before our judiciary today relating to environment. I am sure the number of cases will increase. We need specialised environmental courts. The Supreme Court has said this. The Law Commission has said this. India will be one of the few countries which will have such a specialised environmental court. I believe Australia and New Zealand are the two countries that have specialised Tribunals. ${ }^{96}$

Thus, the MoEF acquired illustrative support and direction from Australian and New Zealand specialized environmental tribunals staffed by judges and expert commissioners, generally, being persons with expert knowledge in environmental matters. The government proposed the creation of a circuit system for the new tribunal. The government proposed four regional benches across the country. According to the minister, "a circuit approach would be followed to enable access for people. The court will go to the people. People would not come to the court. I assure you this." 97

The Bill was passed by the Lok Sabha on 23 April 2010 and Rajya Sabha on 5 May 2010. The NGT Act 2010 received presidential assent on 2 June $2010 .{ }^{98}$ The NGT Act implements India's commitments made at the Stockholm Declaration of 1972 and the Rio Conference of 1992, to take appropriate steps for the protection and improvement of the human environment and provide effective access to judicial and administrative proceedings, including redress and remedies.

The NGT was established on 18 October 2010 and became operational on 5 May 2011 with New Delhi selected as the site for the principal bench. ${ }^{99}$ The regional benches found their home in Bhopal for the central zone, Chennai for south India, Pune for the western territory, and Kolkata is responsible for the eastern region. ${ }^{100}$ Additionally, to become more

\footnotetext{
95. Prsindia.org (2009).

96. Statement by Jairam Ramesh, former Minister of Environment and Forests, Indian Parliament, 30 April 2010.

97. Ibid.

98. Gazette of India Extraordinary (No 19 of 2010); National Environment Tribunal Act No 27 of 1995 (http://www. envfor.nic.in/legis/others/Tribunal.html).

99. Ministry of Environment and Forests Notification, May 2011, S.O.1003 E.

100. Ministry of Environment and Forests Notification, 17 August 2011, S.O.1908 E.
} 
accessible, especially in remote areas, the NGT follows the circuit procedure of courts going to people and not people coming to the courts. Shimla has received circuit benches from Delhi, ${ }^{101}$ as has Jodhpur from the central zone, ${ }^{102}$ Meghalaya from the eastern zone, ${ }^{103}$ and Kochi from the southern zone. ${ }^{104}$

Further, as a learning new concept, the NGT was envisioned as a multifaceted and multiskilled body in which the joint decision-makers held relevant qualifications and appropriate work experience either in law or in technical fields. Accordingly, the technical experts became "central," rather than "marginal," to the NGT's normative structure. The combination of legal, scientific, and technical expertise had a dynamic impact on the content and development of environmental policies and law.

From 2011 onwards, both the external and internal "driving forces" displayed "new learning" in the NGT. The Supreme Court of India in 2012 re-engaged as an external driving force to institutionalize the NGT. The establishment of the NGT encouraged the Supreme Court to review its own environmental case-load and consider its limited environmental expertise. The Supreme Court in Bhopal Gas Peedith Mahila Udyog Sangathan v. Union of India ${ }^{105}$ transferred all environmental cases, both active and prospective, to the NGT to render expeditious and specialized judgments and to avoid the likelihood of conflicts of orders between High Courts and the NGT. The court ordered:

in unambiguous terms, we direct that all the matters instituted after coming into force of the NGT Act and which are covered under the provisions of the NGT Act shall stand transferred and can be instituted only before the NGT. This will help in rendering expeditious and specialized justice in the field of environment to all concerned. ${ }^{106}$

The Supreme Court of India again transferred more than 300 cases to the NGT in 2015. The Green Bench of the Supreme Court, headed by the then Chief Justice H. L. Dattu, decided to release several cases for swift decisions, thereby also shedding its pendency. ${ }^{107}$

\subsubsection{Learning New Meaning for Old Concepts}

Internally, the NGT demarcated the operational changes by redefining the intellectual activity that embraced environmental disputes. Learning new meaning for old concepts was the second step reflecting "new learning" in the NGT. These internal forces within the tribunal corresponded to and helped the NGT to realize the vision of institutionalizing the larger welfare and interest of the society and environmental protection. They supported the attainment of the objectives of prevention and protection of environmental pollution,

\footnotetext{
101. NGT/PB/157/2013/331, 20 December 2013 (office order).

102. NGT/PB/266/2013/281, 2 December 2013 (office order).

103. NGT/PB/Pr/CB/97/2014/M78.

104. NGT/PB/266/2015/299.

105. Bhopal Gas Peedith Mahila Udyog Sangathan v. Union of India (2012) 8 SCC 326.

106. Ibid., p. 347. It is interesting to note that, in Adarsh Cooperative Housing Society Ltd v. Union of India, Order, 10 March 2014, the Supreme Court stayed its own order by which it transferred all environmental cases from High Courts to the NGT. In Vellore Citizen Welfare Forum v. Union of India 2016 SCC Online Mad 1881, the Madras High Court stated "however, it appears that the application was withdrawn on 11.8.2014" (para. 78).

107. T. N. Godavarman Thirumulpad v. Union of India, Order, 5 November 2015.
} 
provide administration of environmental justice, and made them more accessible within the framework of the statute. There was a need to enhance the principles of environmental democracy and rule of law that include fairness, public participation, transparency, and accountability. In-house expertise with knowledge and skills came via a new visionary CEO (Chairperson Kumar in the case of the NGT). Change occurred through task and social leadership and customer-oriented demand (the litigants and lawyers) to access environmental justice.

In terms of learning new meaning for old concepts, "standing" was reformulated in terms of "an aggrieved person" 108 who has the right to approach the tribunal under its original ${ }^{109}$ or appellate jurisdiction ${ }^{110}$ under the NGT Act. Traditionally in India, the concept of litigant "standing" in environmental matters has been broad and liberal, facilitated by public interest litigation (PIL) through two ways, namely representative and citizen standing. The Supreme Court acting as "amicus environment" locked together the issues of human rights and the environment to develop sui generis environmental discourse entertaining PIL petitions, seeking remedies, including guidelines and directions in the absence of legislation. ${ }^{111}$

The NGT in a similar manner created receptive, accessible opportunities for the dispossessed and representative non-governmental organizations (NGOs), through the encompassing term "aggrieved person," the genesis of which is derived from PIL. It championed parity of participation, thereby alleviating inequality and promoting recognition, capabilities, and functioning of individuals and communities in India's environmental justice discourse. The NGT, in Samir Mehta v. Union of India, ${ }^{112}$ explained the scope and ambit of the term. The tribunal stated:

108. Aggrieved party, supra note 68.

109. Section 14 NGT Act 2010 states: "the Tribunal shall have the jurisdiction over all civil cases where a substantial question relating to environment (including enforcement of any legal right relating to environment), is involved and such question arises out of the implementation of the enactments specified in Schedule I." The enactments in Schedule I include: Water (Prevention and Control of Pollution) Act 1974; the Water (Prevention and Control of Pollution) Cess Act 1977; the Forests (Conservation) Act 1980; the Air (Prevention and Control of Pollution) Act 1981; the Environment (Protection) Act 1986; the Public Liability Insurance Act 1981; and the Biological Diversity Act 2002.

110. Section 16 NGT Act 2010 states: "any person aggrieved by an order or decision made, on or after the commencement of the National Green Tribunal Act, 2010, by the (a) Appellate Authority under section 28 of the Water (Prevention and Control of Pollution) Act, 1974; (b) State Government under section 29 of the Water (Prevention and Control of Pollution) Act, 1974 (c) a Board, under section 33 A of the Water (Prevention and Control of Pollution) Act, 1974 (6 of 1974); (d) Appellate Authority under section 13 of the Water (Prevention and Control of Pollution) Cess Act, 1977; (e) State Government or other authority under section 2 of the Forest (Conservation) Act, 1980; (f) Appellate Authority under section 31 of the Air (Prevention and Control of Pollution) Act, 1981; (g) any direction issued under section 5 of the Environment (Protection) Act, 1986; (h) granting environmental clearance in the area in which any industries, operations or processes or class of industries, operations and processes shall not be carried out or shall be carried out subject to certain safeguards under the Environment (Protection) Act, 1986 (i) refusing to grant environmental clearance for carrying out any activity or operation or process under the Environment (Protection) Act, 1986; (j) any determination of benefit sharing or order made by the National Biodiversity Authority or a State Biodiversity Board under the provisions of the Biological Diversity Act, 2002, may, within a period of thirty days from the date on which the order or decision or direction or determination is communicated to him, prefer an appeal to the Tribunal: Provided that the Tribunal may, if it is satisfied that the appellant was prevented by sufficient cause from ling the appeal within the said period, allow it to be led under this section within a further period not exceeding sixty days."

111. State of Uttranchal v. Balwant Singh Chaufal 20103 SCC 402; M. C. Mehta v. Kamal Nath 2006 SCC 213; In re Noise Pollution v. AIR 2005 SC 3136; Chhetriya Pradushan Mukti Sangharsh Samitiv. State of Uttar Pradesh AIR 1990 SC 2060; Subhash Kumar v. State of Bihar AIR 1991 SC 420; Vellore Citizen Welfare Forum v. Union of India AIR 1996 SC 2715; AP Pollution Control Board v. Prof M.V. Nayudu AIR 1999 SC 812; Narmada Bachao Andolan v. Union of India AIR 2000 SC 3751. See also Gill (2012), p. 201; Sahu (2008), p. 380; Faure \& Raja (2010), p. 225; Gill (2015) pp. 140-6; Rajamani (2007), pp. 293-4.

112. Samir Mehta v. Union of India, Judgment, 2 August 2016. 
An "aggrieved person" is to be given a liberal interpretation ... it is an inclusive but not exhaustive definition and includes an individual, even a juridical person in any form. Environment is not a subject which is person oriented but is society centric. The impact of environment is normally felt by a larger section of the society. Whenever environment is diluted or eroded the results are not person specific. There could be cases where a person had not suffered personal injury or may not be even aggrieved personally because he may be staying at some distance from the place of occurrence or where the environmental disaster has occurred and/or the places of accident. To say that he could not bring an action, in the larger public interest and for the protection of the environment, ecology and for restitution or for remedial measures that should be taken, would be an argument without substance. At best, the person has to show that he is directly or indirectly concerned with adverse environmental impacts. The construction that will help in achieving the cause of the Act should be accepted and not the one which would result in deprivation of rights created under the statute. ${ }^{113}$

The liberal approach of the tribunal based upon the benefits of PIL is evidenced in a series of cases. ${ }^{114}$ Two reasons explain this approach. The first is the inability of persons due to poverty, ignorance, or illiteracy, living in the area or vicinity of the proposed project to understand the intrinsic scientific details coupled with the effects of the ultimate project and any disaster it may cause. Thus, it is the right of any citizen or NGO to approach the tribunal regardless of whether being directly affected by a developmental project or whether a resident of affected area or not. Second, the subservience of statutory provisions of NGT Act 2010 to the constitutional mandate of Article $51 \mathrm{~A}(\mathrm{~g})$ establishes a fundamental duty of every citizen to protect and improve the natural environment.

Recent work ${ }^{115}$ provides evidence that identifies the parties to environmental disputes by analyzing some 1,130 cases decided by the NGT between July 2011 and September 2015. The most frequent plaintiffs were NGOs/social activists/public-spirited citizens. They account for 533 plaintiffs (47.2\%) of 1,130 cases. For example, in Vimal Bhai v. Ministry of Environment and Forests, ${ }^{116}$ the tribunal allowed an application by three environmentalists concerning the grant of an environmental clearance for the construction of a dam for hydroelectric power. The NGT ruled that the environmentalists constituted an aggrieved party and their claim for a public hearing concerning the granting of an environmental clearance was sustainable. Overall, the plaintiff group success rate stood at $38.3 \%$. This significant number demonstrates both the opportunity of and the ability of public-spirited citizens and organizations to use the NGT as a route to seek remedies through collective proceedings instead of being driven into an expensive plurality of litigation.

Affected individuals/communities/residents brought $17.7 \%$ of all cases, with a success rate of 56\%. For example, in R. J. Koli v. State of Maharashtra, ${ }^{117}$ the tribunal allowed an application filed and argued in person by traditional fishermen seeking compensation for loss of livelihood due to infrastructural project activities. The positive encouragement by the NGT to litigants in person reflects a conscious effort on the part of the tribunal to promote access to

113. Ibid., paras $31,32$.

114. Kishan Lal Gera v. State of Haryana 2015 ALL (I) NGT REPORTER (2) (DELHI) 286; Sri Ranganathan v. Union of India (2014) ALL (I) NGT REPORTER (2) (SZ) 1; Vithal Gopichand Bhugersay v. Ganga K. Head Sugar and Energy Ltd (2014) ALL (I) NGT REPORTER (1) (SZ) 49; Jan Chetna v. Ministry of Environment and Forests, Judgment, 9 February 2012.

115. Gill, supra note 17, pp. 194-6.

116. Vimal Bhai v. Ministry of Environment and Forests, Judgment, 14 December 2011.

117. R. J. Koli v. State of Maharashtra, Judgment, 27 February 2015. 
environmental justice. Indigent and illiterate litigants have been encouraged to speak in their vernacular language (especially at regional benches) to ventilate their grievances and personal and community experiences. Confidence-building in the NGT has resulted in motivating litigation from within groups that traditionally had little or no access to justice. This reflects the NGT's broad-based, people-oriented approach. The liberal interpretation of "aggrieved person" opened access to the tribunal to promote diffused and meta-individual rights. The NGT's legitimacy is grounded in its inclusive participatory mechanisms.

Additionally, the NGT accepted "eco-centrism"- - a nature-centred approach within its mandate of learning new meaning for old concepts. This is an emerging area wherein the tribunal recognizes and considers that conservation and protection of nature and inanimate objects are inextricable parts of life. ${ }^{118}$ They have an impact on human wellbeing, as they form the life support system of planet Earth. The NGT, in its judgment in Tribunal on Its Own Motion v. Secretary of State, ${ }^{119}$ recognized this approach by following the Supreme Court judgment in Centre for Environment Law, WWF- I v. Union of India ${ }^{120}$ and stated "eco-centrism is, therefore, life-centred, nature-centred where nature includes both humans and non-humans. Article 21 of the Constitution of India protects not only the human rights but also casts an obligation on human beings to protect and preserve a species becoming extinct, conservation and protection of environment is an inseparable part of right to life."121

The learning new meaning for old concepts was further affirmed by the in-house judicial and technical experts through "trial and error learning based on scanning the environment" or, putting it simply, "inventing our own solutions until something works." 122 The traditional adversarial judicial procedures associated with case management and disposal of the individual case have been altered because of the jurisdictional power and promotional activity of the NGT. Thus, centralizing scientific experts, as full court members, within the decisionmaking process promoted a collective, decision-making, symbiotic, interdisciplinary bench seeking to harmonize legal norms with scientific knowledge.

In its commitment to resolve environmental issues, the NGT members expanded and developed new procedures and powers that provided steadfast foundations to guide decisionmaking in environmental matters based upon a rights-based approach. Environmental dispute litigation in the NGT is not simply adversarial in nature. It is quasi-adversarial, quasiinvestigative, and quasi-inquisitorial in nature to promote effective participatory parity and involvement of the person aggrieved-for instance, the adoption of an investigative procedure involving the inspection of affected sites by expert members. ${ }^{123}$ The purpose of site

118. In Intellectual Forum, Tirupathi v. State of AP AIR 2006 SC 1350, the Supreme Court of India recognized "all human beings have a fundamental right to a healthy environment commensurate with their well-being ... ensuring that natural resources are conserved and preserved in such a way that present as well as the future generation are aware of them equally" (para. 84).

119. Tribunal on Its Own Motion v. Secretary of State, Judgment, 4 April 2014.

120. Centre for Environment Law, WWF-I v. Union of India (2013) 8 SCC 234.

121. Ibid., p. 256, emphasis in original. Also see Sudeip Shrivastava v. State of Chattisgarh, Judgment, 24 March 2014; Charudatt P. Koli v. M/s Sea Lord Containers, Judgment, 18 December 2015.

122. Schein, supra note 39, pp. 310-11.

123. Forward Foundation v. State of Karnataka, Judgment, 10 September 2015. In MoEF v. Nirma Ltd, Order of the Supreme Court, 4 August 2014, the Supreme Court found nothing wrong with the procedure adopted by the NGT requiring two of its technical members to visit the site and make a report after carrying out a personal inspection. 
inspections is to evaluate contradictory claims, positions, and reports filed by the respective parties.

The stakeholder consultative adjudicatory process is the most recent of the NGT's problem-solving procedures. Major issues having a public impact either on public health, environment, or ecology can be better handled and resolved when stakeholders are brought together alongside the tribunal's scientific judges to elicit the views of those concernedgovernment, scientists, NGOs, the public, and the NGT. Stakeholder process evokes a greater element of consent rather than subsequent opposition to a judgment. The ongoing Ganga river, ${ }^{124}$ Yamuna river, ${ }^{125}$ and air pollution ${ }^{126}$ cases are illustrations of the new stakeholder consultative adjudicatory process involving open dialogue with interested parties. In K. K. Singh v. National Ganga River Basin, ${ }^{127}$ the NGT observed:

the Tribunal adopted the mechanism of "Stakeholder Consultative Process in Adjudication" to achieve a fast and implementable resolution to this serious and challenging environmental issue facing the country. Secretaries from Government of India, Chief Secretaries of the respective States, concerned Member Secretaries of Pollution Control Boards, Uttarakhand Jal Nigam, Uttar Pradesh Jal Nigam, Urban Development Secretaries from the States, representatives from various Associations of Industries (Big or Small) and even the persons having least stakes were required to participate in the consultative meetings. Various mechanism and remedial steps for preventing and controlling pollution of river Ganga were discussed at length. The purpose of these meetings was primarily to know the intent of the executives and political will of the representative States who were required to take steps in that direction. ${ }^{128}$

In this way, efforts are being made to ensure scientifically driven judgments reflect the interests, expectations, and plans of stakeholders to produce decisions that support sustainable development and recognize the wider public interest.

The exercise of suo motu power (on its own motion) proceedings in environmental cases is another situation indicating learning new meaning for old concepts. In suo motu proceedings, a superior court initiates proceedings as PIL in the public interest and acts on its own volition in the absence of parties. ${ }^{129}$ The NGT's jurisdiction is typically triggered by an aggrieved person filing a motion. Interestingly, the NGT Act 2010 does not expressly provide the authority to initiate suo motu proceedings. Cases such as increased vehicular traffic in Himachal Pradesh, ${ }^{130}$ dolomite mining in the tiger reserve forest in Kanha National

124. K. K. Singh v. National Ganga River Basin Authority, Judgment, 16 October 2014.

125. Manoj Mishra v. Union of India NGT, Judgment, 13 January 2015 (now referred to as the Maily se Nirmal Yamuna Revitalization Plan 2017).

126. Vardhaman Kaushik v. Union of India and Sanjay Kulshrestha v. Union of India, Order, 7 April 2015.

127. K. K. Singh v. National Ganga River Basin Authority, supra note 124.

128. Ibid., para. 3.

129. Suo-motu power is exercised by the superior constitutional courts. It is a plenary power to meet the demands of justice. Where there is a flagrant violation of a mandatory provision of either any statute or any constitutional mandate, it is the duty of the superior court to set aside the illegality in the judgment, as it is well settled that illegality should not be perpetuated and failure by the court to interfere would amount to allowing illegality to be perpetuated. See Galanter (2014), p. 74. Galanter argues that the suo-motu judicial "initiatives derive from judicial reaction to a newspaper article or a letter (the so-called 'epistolary jurisdiction'), which have become a familiar feature of the Indian judicial scene, rare but highly visible." See also In re Amarnath Shrine (2013) 3 SCC 247; Pawan Kumar v. State of Haryana (2003) 11 SCC 241.

130. Court on Its Own Motion v. State of Himachal Pradesh, Judgment, 6 February 2014. 
Park, ${ }^{131}$ groundwater contamination in the water supply lines and bore wells in Delhi, ${ }^{132}$ and the clearing and felling of trees in the Sathyamanglam Tiger Reserve ${ }^{133}$ are illustrative of the NGT initiating controversial suo motu proceedings. These cases reflect the tribunal's self-proclaimed, expansionist power to review environmental issues, ab initio, simply on the grounds of environmental protection and human welfare. For the tribunal, "suo motu jurisdiction has to be an integral part of the NGT for better and effective functioning of the institution. There are some inherent powers which are vital for effective functioning and suo motu jurisdiction is one such power."134

The NGT also conferred upon itself the power of judicial review-yet another important and controversial instance of learning new meaning for old concepts. The Constitution of India vests the Supreme Court under Article 32 and High Courts under Article 226 with the power of judicial review to ascertain the legality of legislation or an executive action. ${ }^{135}$ However, the power of a tribunal as a "quasi-judicial body" to undertake the judicial review has often been disputed. ${ }^{136}$ In L. Chandra Kumar v. Union of India, ${ }^{137}$ the Supreme Court observed:

the Tribunals are not substitutes for the High Courts, and they can carry out only a supplemental, as opposed to substitutional role, since the power of the High Courts and Supreme Court to test the constitutional validity of legislations can never be ousted or excluded. The Tribunals are therefore not vested with the power of judicial review to the exclusion of the High Courts and the Supreme Court. ${ }^{138}$

However, in a series of cases, ${ }^{139}$ the NGT declared the tribunal is competent and is vested with the jurisdiction and power of judicial review. The tribunal has all the characteristics of a court and exercises the twin powers of judicial as well as merit review. There is no provision in the NGT Act 2010 that curtails its jurisdiction to examine the legality, validity, and correctness of delegated legislation regarding the Acts stated in Schedule I to the NGT Act 2010. ${ }^{140}$

131. Tribunal on Its Own Motion v. Secretary, MoEF, Judgment, 4 April 2014.

132. Tribunal on Its Own Motion v. Government of NCT, Delhi Order, 19 June 2015.

133. Tribunal on Its Own Motion v. Union of India 2013 SCC Online 1095.

134. Downtoearth.org (2014). Statement made by the then chairperson, Justice Swatanter Kumar. Also see Tribunal on Its Own Motion v. District Collector, Sivaganga District 2014 SCC On Line 1450 to prevent pollution of the Sambai; Tribunal on Its Own Motion v. Union of India 2014 SCC OnLine 1433 on a news item published in The Hindu dated 21 November 2013 under the caption "Plan for stadium at Tirupathi raises eyebrows"; Tribunal on Its Own Motion v. Union of India 2014 SCC On Line 2352 about "Setting up of petrol bunk in Sathyamangalam Reserve forest" published in The Hindu dated 1 August 2013; Tribunal on Its Own Motion v. The Secretary MoEF 2013 SCC OnLine 1086 regarding unauthorized constructions in Muttukadu coastal zone, report in New Indian Express dated 7 July 2013; Tribunal on Its Own Motion v. State of Tamil Nadu, Municipal Administration and Water Supply Department 2013 SCC Online 1105 regarding quality water to be delivered by public tap, based on letter dated 24 July 2013 from Shri Ramchandra Srivatsav.

135. Minerva Mills Ltd. v. Union of India AIR 1980 SC 1789. It is settled law that judicial review is a part of the basic structure of the Indian Constitution that "cannot be abrogated without affecting the basic structure of the Constitution."

136. Law Commission of India, supra note 93, pp. 54-64.

137. L. Chandra Kumar v. Union of India (1997) 3 SCC 261.

138. Ibid., p. 302.

139. Wilfred J. v. Union of India NGT, Judgment, 17 July 2014; Kalpvriksh v. Union of India, 17 July 2014; S. P. Muthuraman v. Union of India, Judgment, 1 September 2015; Himmat Singh Shekhawat v. State of Rajasthan, Judgment, 13 January 2015; Society for Protection of Biodiversity v. Union of India, Judgment, 8 November 2017.

140. In the Union of India v. Major General Shri Kant Sharma (2015) 6 SCC 773 case, though it pertained to the Armed Forces Tribunal Act 2007, the Supreme Court observed "the jurisdiction of the High Court under Article 226 Constitution of India may not be circumscribed by the provisions of any enactment. However, due regard should be given to the legislative intent evidenced by provisions of the Acts and courts would exercise their jurisdiction consistent with the provisions of the Acts. When a statutory forum is created by law for redressal of grievances, a writ petition 
The exercise of judicial review has evoked mixed responses. Environmentalists felt a strong message is delivered that the NGT is concerned with not only the merits of the decision, but also the decision-making process. As an independent body, the NGT aims to protect individuals against abuse or misuse of power by the authorities. ${ }^{141}$ However, the MoEF on the other hand felt that it amounted to usurping its jurisdiction. It claimed that the NGT can only examine decisions and cannot strike down a statute. ${ }^{142}$

The NGT's willingness regarding "inventing our own solutions until something works" to resolve the environmental issues reflects its expansive self-created procedure for learning new meaning for old concepts. Consequently, it produced changes in both the institutional and the external landscapes by antagonizing certain state High Courts and furthering the distance from the MoEF.

\subsubsection{Adopting New Standards of Evaluation}

Along with the new concepts comes adopting new standards of evaluation for a transformation change encouraged by drastically increased environmental problems including a rise in pollution levels and demographic pressures. "Cost and time" help in evaluating the standards in an organization for customer expectation. ${ }^{143}$ Contextualizing within the NGT, adopting new standards of evaluation envisages "aggrieved person" expectation for a faster, cheaper, and more effective way to access to environmental justice, thereby promoting participatory parity. The internal driving force of the NGT, through its leadership and regulatory requirements, helps in evaluating the measurable standards. It allows aggrieved persons to initiate proceedings before the NGT and "assert diffused and meta-individual

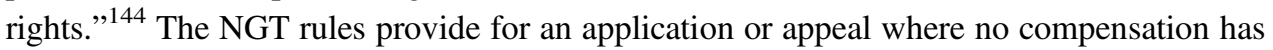
been claimed to be accompanied by a fee of INR 1,000 (GBP 10). ${ }^{145}$ Where compensation is claimed, the fee is equivalent to $1 \%$ of that compensation, subject to a minimum of INR 1,000 (GBP 10). ${ }^{146}$ Thus, the low fees reflect the NGT's open-door commitment to the poor. Another feature of the NGT is its ability to fast-track and decide cases within six months of application or appeal. ${ }^{147}$ To illustrate, Figure 5 demonstrates the status of NGT litigation as of 31 July 2017.

The official figures show 23,095 cases were filed, of which 19,740 were decided and 3,355 were pending before the NGT. This demonstrates that $85.4 \%$ of the cases were decided whereas $14.6 \%$ of cases remained pending. The NGT's legitimacy is grounded in its inclusive participatory mechanisms (standing, time, and costs) that promote dynamism and

\footnotetext{
(F'note continued) Choudhary.

142. Ibid.

143. Schein, supra note 39 , p. 309.

144. Sahu, supra note 111, p. 379.

145. The NGT (Practices and Procedure) Rules 2011, supra note 69.

146. Ibid., Rule 12(1).

147. NGT Act 2010, supra note 70.
}

should not be entertained ignoring the statutory dispensation." However, the value of this judgment has been questioned in the case of Union of India v. Thomas Vaidyan M., Civil Appeal No. 5327/2015, order dated 16 November 2015. The Supreme Court has observed that the jurisdictional aspect be considered by a three-judge bench, as the matter involves some urgency. The issue is pending before the larger bench of the Supreme Court of India.

141. Polanki (2014). Statement by environmental activists (who happen to be lawyers) Ritwick Dutta and Rahul 


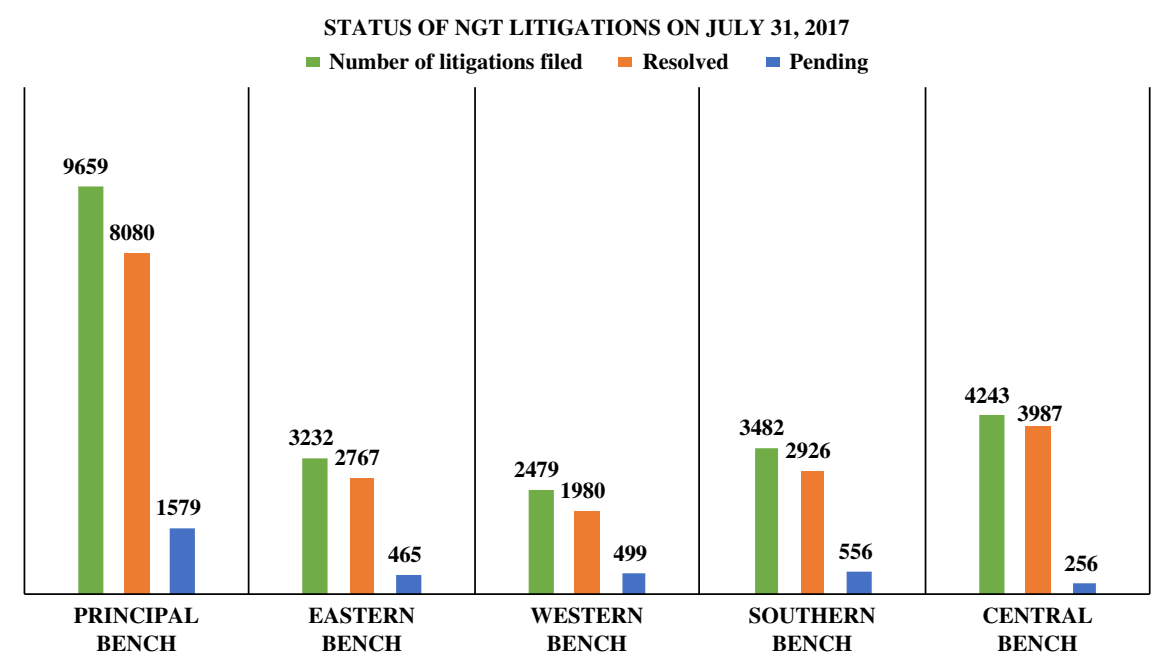

Figure 5. Status of litigation in the five NGT benches. Source: NGT Annual Report 2017

capability, thereby providing victims of environmental degradation with access to the tribunal.

Thus, the institutionalization and transformation sought by the NGT are a metamorphosis of societal environmental interests that encapsulate the wellbeing of not only the individual, but also the larger public interest. The relative position of the inter-dependent "driving forces" (MoEF until 2011, Supreme Court of India, and the NGT's internal forces) came together and expressed themselves for "new learning" by the establishment of an organized institution: the NGT through internal procedural expansion and change.

\subsubsection{New Learning, Change, and the Restraining Forces in Action}

However, this stage of "new learning" has not occurred without struggle. There existed "restraining forces." The MoEF after 2011 and the High Courts gained momentum and strength to restrict the proactive NGT as it sought to take control of the intellectual space for the right to regulate or respond to environmental issues.

From its inception, and particularly after 2011, the NGT faced institutional challenges due to limited co-operation and hesitant operational commitment of MoEF and state governments. Initially, the understaffed bench and inadequate logistic and infrastructure facilities, coupled with inappropriate housing for bench appointees, led to the resignation of three judicial members: Justices C. v. Ramulu, Amit Talukdar, and A. S. Naidu. ${ }^{148}$ The state's inaction required intervention by the Supreme Court to remedy the situation. ${ }^{149}$ Senior counsel, Gopal Subramaniam, appeared on behalf of the NGT and informed the Supreme Court about "a very sorry state of affairs" affecting the tribunal. He said:

the members have been put up in the middle of quarters of Class III and IV employees. The initial budget of INR 32 crores [GBP 3,505,462] was slashed to INR 10 crores [GBP 1,095,513] to be further reduced to INR 6 crores [GBP 657,308]. Each of the members is paying from his own

148. Shrivastava (2012).

149. Union of India v. Vimal Bhai, SLP No 12065 of 2009. 
pocket for travel. They don't even have a supply of food at work and they are compelled to get food from the canteen. Is this how the government proposes to treat the sitting and former judges of the High Courts and Supreme Court of India? ${ }^{150}$

The Supreme Court described the treatment experienced by the members of the NGT as "utterly disgusting." 151 Accordingly, the Supreme Court stated that the NGT benches must become fully functional by 30 April 2013.

The Bhopal bench started functioning in the basement of a building, despite affidavits being led by the state government claiming suitable accommodation had been provided to the NGT. Justice Singhvi reacted sharply by observing "we cannot appreciate that a misleading statement was made before the highest court. A false affidavit was led before the apex court. Accommodation does not mean basement." ${ }^{\text {152 }}$ The Pune bench was treated in a similar derisory manner. It was inaugurated on 17 February 2012, but the lack of state support resulted in delays into March 2013. Kolkata fared even worse. The state of West Bengal failed to respond to the orders of the Supreme Court. The NGT chairperson inspected the Kolkata bench and found the premises, particularly the accommodation offered to judges, to be "shabby, uninhabitable and without a toilet."153

There is an explanation for this degrading treatment that affected the establishment and the early operational effectiveness of the NGT benches. There existed an unresponsive and dysfunctional state administration that failed to appreciate the importance of green issues. The then MoEF Minister Jairam Ramesh was known for raising the green profile and hailed by many as an outstanding environment minister. Nevertheless, he was fighting battles within his own ministry, the MoEF. Personally, "he remained accessible and responsive but he could not ensure that his ministry officials were also accessible and responsive." 154 Ramesh described the ministry's environmental working position as:

It's a huge bureaucracy. There is a structural problem .... It's easier to reform laws and procedures and hope that would create a new mind-set in these people rather than try for a structural change .... This is not a ministry where at the end of the day I can say that I put 10,000 mw of generating capacity, I have started 300 trains, or I opened 60 new mines. It's basically a regulatory institution. To that extent unidirectional goals are very difficult to achieve. ${ }^{155}$

Former minister Ramesh supported and guided the enacting NGT Bill through Parliament but was unable to establish and promote the benches due to his removal from the MoEF in 2011. ${ }^{156}$ From 2011 onwards, the "restraining forces" within the MoEF reflected structural inertia, resistance to change, and indifference to an extent that they were reluctant to provide appropriate financial and structural support.

Additionally, the "new learning" stage witnessed the MoEF and High Courts acting as "restraining forces" questioning the alleged self-validation by the tribunal of further jurisdictional powers. The colonization of intellectual space partly by the public promotion of

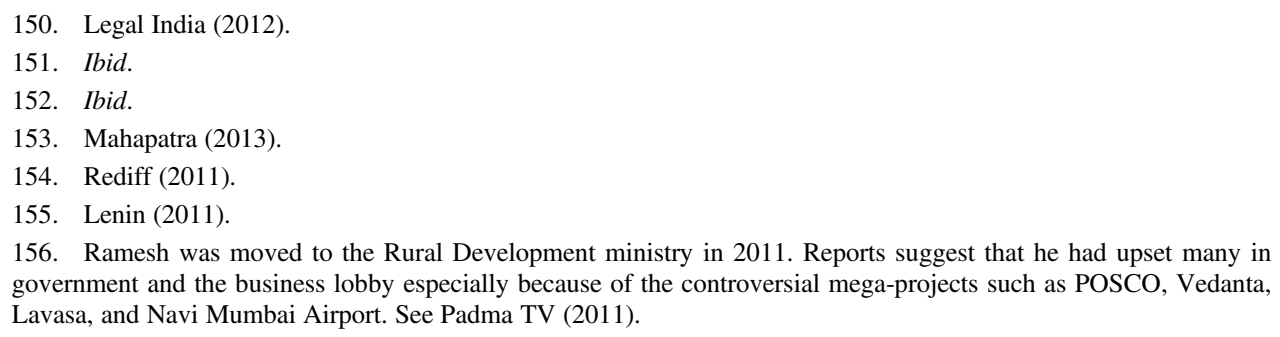


its jurisdiction and through its effectiveness in protecting both the environment and the interests of affected parties was not well received by the MoEF and some High Courts.

The exercise of suo moto powers by the NGT was raised and challenged by the MoEF. The ministry had refused to confer this power on the tribunal despite repeated requests to do so. In an affidavit before the Supreme Court of India in 2013, the MoEF stated:

the government of India has not agreed to confer suo motu powers on the Tribunal. It is for the NGT, an adjudicatory body, to follow the provisions of the NGT Act 2010 ... resulting in embarrassment to the government before Parliament. ${ }^{157}$

The claim of alleged judicial overreach was bolstered when the High Court of Madras restrained the NGT Chennai bench from initiating suo motu proceedings. The High Court stated:

NGT is not a substitute for the High Courts. The Tribunal has to function within the parameters laid down by the NGT Act 2010. It should act within four corners of the statute. There is no indication in the NGT Act or the rules made thereunder with regard to the power of the NGT to initiate suo motu proceedings against anyone, including statutory authorities. ${ }^{158}$

Further, an order passed by Madras High Court dated 7 July 2015 stated that the NGT should not initiate more suo motu proceedings. ${ }^{159}$ Jurisdictional expansion in this regard remains unsettled, although its procedural value is significant. It allows the NGT to initiate proceedings and permits the tribunal to roam far and wide, searching for pressing environmental issues that it considers to be in the public interest.

The NGT's self-defined expansion of powers to include judicial review reflects further territorial extension at the potential cost of alienation and challenge by the High Courts that previously and exclusively enjoyed the exercise of these powers. For example, the Bombay High Court in Central Indian Ayush Drugs Manufacturers Association v. State of Maharashtra ${ }^{160}$ decided that the NGT does not possess power to adjudicate upon the vires or validity of any enactment in Schedule I or of subordinate legislation framed under such enactment. Increasing tribunalization is viewed by some High Courts as serious jurisdictional encroachment, thereby causing institutional confusion, collusion, and complexity. ${ }^{161}$

Figure 6 reflects the interplay of the principal "driving forces" and "restraining forces." The "driving forces" aimed to bring a change whereas the "restraining forces" represent resistance to the change.

However, as the NGT overcame suspicion bordering on hostility with the support of the Supreme Court and its own results-based commitment, it ensured that the terms of the NGT Act 2010 were given practical effect throughout India. Despite initial setbacks and

157. Anand, supra note 21. An affidavit was filed by the MoEF Deputy Secretary R. K. Agrawal. However, the affidavit invited the annoyance of the Supreme Court, as it described it as "breach of all norms of decency."

158. Subramani (2014).

159. P. Sundarajan v. Deputy Registrar NGT (2015) 4 Law Weekly 23, at 27.

160. Judgment in W. P. No. 6360 of 2015 decided on 28 September 2016.

161. For example, constitutional law expert Rajeev Dhawan states "the NGT cannot strike down a statute. It can only examine the decisions that are taken and consider if they are in compliance with the three principles laid down in Section 20 of the Act." Also see Rediff (2013). Justice Ruma Pal, former judge of the Supreme Court of India, questioned: "Who do we include within the term 'judiciary'? Is it limited to constitutional courts or does it also include those Tribunals which decide rights and merely have the trappings of a court?" 


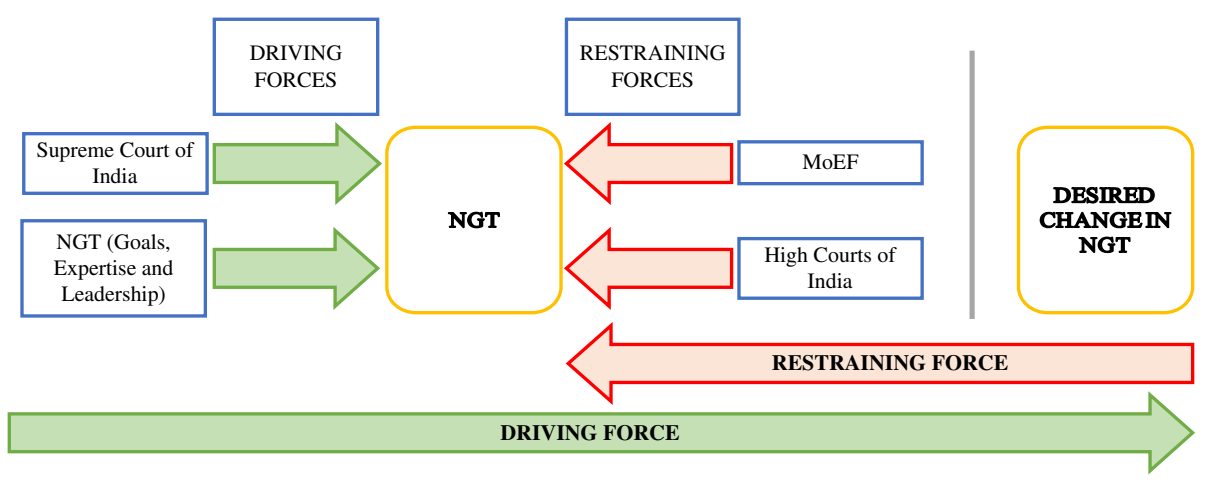

Figure 6. Interplay between driving and restraining forces. Source: Author

continuing concerns from powerful agencies, the "driving forces" outweighed the "restraining forces," allowing the move to the next stage: refreeze.

\subsection{Refreeze}

Lewin and Schein's framework recognizes that refreezing is the final step in any change wherein "the new learning will not stabilize until it is reinforced by actual results."162 Refreezing represents institutionalization of change wherein the "new learning" and behaviour become habitual, as it will "produce better results and be confirmed." ${ }^{163}$ However, the refreeze stage may not be permanent and could lead to the restart of the "three-step model"; if it

does not produce better results, this information will be perceived as a disconfirming information ... systems are, therefore, in perpetual flux, and the more dynamic the environment becomes, the more that may require an almost perpetual change and learning process. ${ }^{164}$

The refreeze stage for the NGT is both complex and contentious.

The institutionalization of the NGT and its reinforcement by actual results indicate that it had moved into the refreeze status. The manifestation of the actual results or outcome is witnessed at both the international and the national levels. Internationally, the NGT is considered as a framework for "the world's largest network of local environmental Tribunals, expected to increase citizen access to environmental justice." 165 Recently, the World Commission on Environmental Law and the Global Judicial Institute on the Environment expressed their great appreciation for the NGT, for its precedent-setting jurisprudence, as well as its international conferences over the several years that successfully brought together parliamentarians, judges, lawyers, scientists, academics, students, and other international and national delegates. ${ }^{166}$

At the national level, the practical testimony to "producing better results" is evidenced by the significant case growth in the NGT. Figure 7 illustrates this growth.

162. Schein, supra note 39 , p. 311.

163. Ibid.

164. Ibid.

165. United Nations Development Programme (2014), p. 13; See also the commendations, pp. 1-2 of this article.

166. iucn.org (2018). 


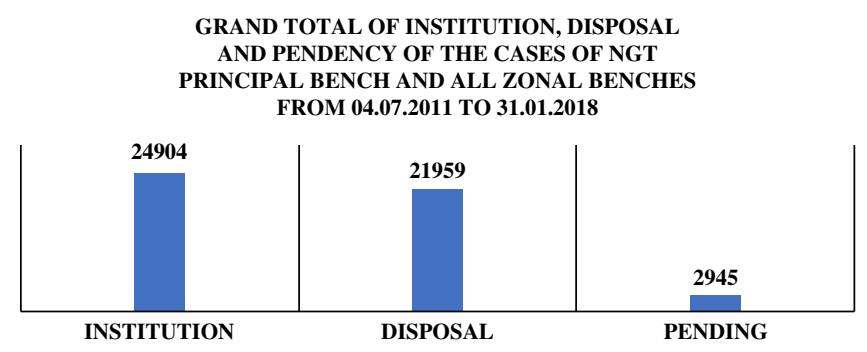

Figure 7. Status of litigation in five NGT benches. Source: NGT website (http://www.greenTribunal. gov.in/)

The NGT has found favour with the common man: "aggrieved person" seeking to access environmental justice. Figure 7 represents the status of NGT litigation from July 2011 to January 2018. The growing public awareness and the confidence in the NGT symbolize widespread credibility that promotes and supports environmental justice.

The performance indicator for actual and better results is further substantiated by the NGT producing judicially binding decisions that offer ecological, technological, and scientific resource knowledge. By reconfiguring its jurisdictional boundaries, its decisions through expansive rationale and innovative judgments go beyond the "courtroom door" with far-reaching social and economic impact. The legal lens has been expanded by the NGT decisions through either formulating policies or assisting state governments with the implementation of these policies, thereby adopting both a problem-solving and a policycreation approach.

A major innovation is the NGT's willingness to offer scientifically based structural planning and policies that respond creatively to weak, ineffective regulation or even the absence of regulation. The scientific experts apply constructive interpretation to expand the scope of rules and regulations if the activity is injurious to public health and environment. Such an interpretation serves the public interest in contrast to the private or individual interest. For example, in Asim Sarode v. Maharashtra Pollution Control Board, ${ }^{167}$ the NGT identified the absence of notified standards for used-tyre disposal. Open tyre burning is toxic and mutagenic. Stock-piled used tyres can also be a health hazard, as they become breeding grounds for diseases and can catch fire. Accordingly, the NGT directed the regulatory agencies to urgently develop regulations dealing systematically with the issue based on the "life-cycle approach," considering the pollution potential, data on tyre generation, technology options, techno-economic viability, and the social implications based on the principles of sustainable development and the precautionary principle. Again, in Haat Supreme Wastech Limited v. State of Haryana, ${ }^{168}$ the NGT expanded the scope of rules relating to bio-medical waste-treatment plants. The Bio-Medical Waste (Management and Handling) Rules 1998 are silent about whether the establishment and operation of a treatment plant require environmental clearance. Bio-medical waste, by its very nature, is hazardous. The tribunal directed that it is mandatory to obtain environmental clearance for the treatment plants. This requirement, when properly carried out, would help to ensure an

167. Judgment, 6 September 2014.

168. Judgment, 28 November 2013. 
appropriate analysis of the suitability of the location and its surroundings, the impact on public health, and a more stringent observation of parameters and standards by the project proponent. $^{169}$

In addition, the NGT adopted an accountability-focused approach whereby a diverse set of actors including governmental and local authorities, companies, and multinational corporations were restrained in compromising human welfare and the ecology. Importantly, in its decisions, the NGT identified the MoEF and related regulatory agencies as demonstrating indifference, ultra vires, or negligence in the exercise of their responsibilities. ${ }^{170}$ In Jai Singh v. Union of India ${ }^{171}$ the NGT identified failure of government and regulatory authorities in preventing and controlling pollution arising from illegal and unauthorized mining, transportation, and running of screening plants and stone crushers. The tribunal stated:

the activity must be brought within the control of legal and regulatory regime. The concerned authorities of the Government and Boards should not only realise their responsibility and statutory obligation but should ensure that there is no unregulated exploitation of the natural resources and degradation to the environment. Respondents, including the State Government, the Boards, MoEF and other concerned authorities have permitted such activity despite orders of the Hon'ble Supreme Court of India, the High Courts and the Tribunal. There is definite evidence on record to show that illegal mining has continued .... Merely denying the authenticity of the photos, videos and other documentary evidences on the pretext that they were doctored would not amount to discharge of the onus placed upon the respondents. ${ }^{172}$

Frequently, the MoEF has been subjected to severe criticism by the NGT for failing to observe its own procedural rules, such as the improper granting of licences without prior environment impact assessments (EIAs) being completed or appropriately conducted. ${ }^{173}$ In India, there have been serious failures regarding cumulative environment impact assessment studies, rendering this crucial process meaningless. For example, in Krishi Vigyan Arogya Sanstha $v$. MoEF, ${ }^{174}$ the tribunal cancelled the grant of environmental clearance for a coalbased thermal-power project in the absence of a proper cumulative environmental impact assessment (CEIA). No scientific assessments were done in relation to expected excess cardiovascular and respiratory mortality, children's asthma, and respiratory dysfunction attributable to the exposure to the air pollutants from the plant, the impact on the water bodies and its impact on aquatic life, and the effect of nuclear radiation in and around the plant. In Prafulla Samantray v. Union of India ${ }^{175}$ (the POSCO case), the issue before the NGT was

169. See also T. Muruganandam v. MoEF, Judgment, 11 November 2014; Samata v. Union of India, Judgment, 13 December 2013; M/S Ardent Steel Ltd v. Union of India, Judgment, 27 May 2014; Pathankot Welfare Association $v$. State of Punjab, Judgment, 25 November 2014.

170. Sarpanch, Grampanchayat Tiroda v. State of Maharashtra, Judgment, 12 September 2011; Jan Chetna v. MoEF, Judgment, 9 February 2012; Prafulla Samantray v. Union of India, Judgment, 30 March 2012; Adivasi Mazdoor Kisan Ekta Sangathan v. MoEF, Judgment, 20 April 2012; Osie Fernandes v. MoEF, Judgment, 30 May 2012; Rohit Choudhary v. Union of India, Judgment, 7 September 2012.

171. Judgment, 18 February 2016.

172. Ibid., para. 93 .

173. Sreeranganathan K. P., Aranmula v. Union of India, Judgment, 28 May 2014; Prafulla Samantray v. Union of India, supra note 170; Rohit Choudhary v. Union of India, supra note 170; Samata v. Union of India NGT, supra note 169; Kalpavriksh v. Union of India, Judgment, 17 July 2014.

174. Judgment, 20 September 2011.

175. Prafulla Samantray v. Union of India, supra note 170. 
opposition to the proposed POSCO project, involving the construction of an integrated steel plant with a service seaport at Paradip in the state of Orissa. The construction of the proposed plant and port threatened the area's unique biodiversity and anticipated the dislocation and displacement of the long-standing forest-dwelling communities. The NGT held no meticulous scientific study was undertaken, leaving lingering and threatening environmental and ecological doubts unanswered. Factors such as the siting of the project, present pollution levels, the impact on surrounding wetlands and mangroves and their biodiversity, risk assessment with respect to the proposed port project, the impact of source-of-water requirements under competing scenarios, and the evaluation of the zero-discharge proposal were not studied. The tribunal required a comprehensive and integrated EIA based on at least one full year of baseline data, especially considering the magnitude of the project and its likely impact on various environmental attributes in the ecologically sensitive area. The initial clearance was set aside as arbitrary and illegal and vitiated in the eyes of law.

The tribunal has been prepared to call senior civil servants to the court having heard often inappropriate or implausible explanations from the MoEF and related regulatory authorities' decisions including union and state governments. For example, the NGT stated:

Directions issued by us have not been complied. Though the counsel for MoEF submits that report has been filed which we notice, least we could say about that it is misleading and is not in terms of our direction. The affidavit as directed has not been filed. We direct presence of deponent in the affidavit, namely, Dr Sunamani Kereketta, Director, MoEF before the Tribunal on the next date of hearing. ${ }^{176}$

On occasions, senior civil servants have been told that they face a term of "state hospitality" (jail) for statements bordering on contempt. ${ }^{177}$ Indeed, in Sudeip Shrivastava v. State of Chhattisgarh, ${ }^{178}$ the tribunal took the bold, provocative step of criticizing the Minister of State for Environment and Forest and the MoEF for acting arbitrarily and ignoring relevant material issues that would have contributed to a holistic appraisal of the environmental problem.

The tribunal has on occasions reprimanded the regulatory authorities in the strongest language in open court. Such public criticism has done nothing to endear the tribunal to key agencies and ministerial officials unused to such embarrassing rebuke that exposes their inefficiency or indifference. For instance, in the Ganga pollution case, ${ }^{179}$ the NGT stated "it is really unfortunate that the Ganges continues to be polluted. Why don't you [the state and federal governments] do something? You raise slogans [about cleaning the river] but do exactly opposite of that." 180

In the Delhi air-pollution case, ${ }^{181}$ the NGT commented:

176. Economictimes.indiatimes (2017b).

177. Ibid.

178. Judgment, 24 March 2014.

179. K. K. Singh v. National Ganga River Basin Authority, supra note 124.

180. BBC (2016); also see Economictimes.indiatimes (2017a). The NGT chastised the MoEF for not abiding by its directions on implementation of a notification on air-pollution emission standards and water consumption for coal-based thermal-power plants.

181. In 2014, a young lawyer and environmentalist, Vardhman Kaushik, led a petition (Vardhman Kaushikv. Union of India, Application 21 of 2014) before the Principal Bench of the NGT with a limited pleading to identify and curb the sources of rising air pollution in the National Capital Territory (NCT) of Delhi. The petition has escalated into one of the most important NGT cases. See Hindustan Times (2017); Swachhindia (2017). 
every newspaper has been carrying headline that the air pollution [in Delhi] was going to be higher this week. Still you took no action .... Are people of Delhi supposed to bear this? In this country, it is a dream to have prescribed norms of air quality.

In the Goa Foundation v. Union of India case, ${ }^{182}$ the NGT critically observed:

The MoEF is the "most messy" Ministry, for its changing stance regarding protection of the Western Ghats .... Why can't it (MoEF) take a clear stand on whether it wants to keep the Gadgil report or not? If it can't then we will have to call the MoEF secretary in person to clear the matter .... Despite our specific directions, MoEF has failed to file an appropriate affidavit. A vague affidavit has been presented before the Tribunal today. ${ }^{183}$

Gill's study documents that regulatory agencies (comprising the MoEF, state government, local authorities, and pollution-control boards) constituted 942 defendants (83.4\%) of 1,130 reported judgments between 2011 and 2015. ${ }^{184}$ The MoEF was the defendant in 284 cases (25.1\%); state government appeared as the defendant in 341 cases (30.2\%); a local authority was listed in 78 cases $(6.9 \%)$; and pollution-control boards in 239 cases $(21.2 \%)$. The data suggest a repeated failure on the part of regulatory authorities to undertake their statutory environmental protection duties and social responsibilities regarding environmental matters. The regulatory agencies dealing with environmental matters have been unable to deliver, according to an official enquiry, due to:

a knee-jerk attitude in governance, flabby decision-making processes, ad hoc and piecemeal environmental governance practices .... The institutional failures include lack of enforcement, flawed regulatory regime, poor management of resources, inadequate use of technology; absence of a credible, effective enforcement machinery; governance constraints in management; policy gaps; disincentives to environmental conservation, and so on. ${ }^{185}$

The failure of central and state agencies to follow due process has been a regular and major cause of complaint from aggrieved persons who seek redress from the NGT. The tribunal has proved stubbornly determined and successful in enforcing the environmental regulations. Its case-law demonstrated its ability and willingness to require transparency and accountability that ultimately constitute the building blocks of good governance and environmental democracy.

\subsubsection{Thawing and Restart Process}

However, the institutionalization of the NGT in the refreeze stage has importantly triggered a subsequent thawing or renewal process. The external "restraining forces" slowly and steadily have become sufficiently powerful to destabilize the NGT and set in motion a fresh change. These volatile forces are gaining momentum by creating situations whereby field-level changes become inevitable, and hence the restart of the process. Again, the "restraining forces" include political and economic interests, policy and legislative interventions, and regulatory agencies, particularly the MoEF.

182. Judgment, 18 July 2013. A case was led by two NGOs: Goa Foundation and the Peaceful Society, Goa. They sought directions requiring the state government to take steps for the conservation and protection of another World Heritage Site, the Western Ghats, as requested by the high-powered panel, the Western Ghats Ecology Expert Panel (WGEEP). The Western Ghats are a treasure trove of biological diversity and are recognized as a global "hotspot of biodiversity."

183. Ghosal (2014); Aggarwal (2014).

184. Gill, supra note 17, pp. 196-7.

185. High-Level Committee on Forest and Environment Related Laws (2014), pp. 8, 22. 
Economic interests and the national growth agenda are powerful "restraining forces" impacting upon the NGT. The current national economic strategy has assumed heightened significance under the leadership of India's prime minister, Narendra Modi. He is known for his ability to drive change and his commitment to accelerate sustainable growth in India. Prime Minister Modi, at the February 2018 World Sustainable Development Summit, emphasized the current environmental problems being faced by the developing nations and the need for a development process that is inclusive and sustainable, resulting in benefit to all stakeholders: ${ }^{186}$

This summit is a reinforcement of India's commitment to a sustainable planet, for ourselves and for future generations. As a nation, we are proud of our long history and tradition of harmonious coexistence between man and nature. Respect for nature is an integral part of our value system. Our traditional practices contribute to a sustainable lifestyle. Our goal is to be able to live up to our ancient texts which say, "Keep pure For the Earth is our Mother and we are her children." India has always believed in making the benefits of good governance reach everyone. Our mission of "Sabka Saath Sabka Vikas" is an extension of this philosophy. Through this philosophy, we are ensuring that some of our most deprived areas experience social and economic progress on par with others. ${ }^{187}$

Nevertheless, Modi is also known as a pro-business, market-oriented reformer who aims to double the Indian economy in the next seven years. Modi claims "India would have a \$5 trillion economy by 2025."188 Modi's efforts in building India's global appeal for investors by introducing an "ease of doing business" strategy has yielded returns. India rose 30 places to 100 in the World Bank's Ease of Doing Business global rankings and was named as one of the top ten countries in reforming its business environment. ${ }^{189}$

Notwithstanding these ambitious commitments, the reality within India remains disturbing. There continues to exist a failure gap between the public statements of Prime Minister Modi and their application in practice by his "agents," being the relevant ministries, regulatory agencies, and civil servants. An illustration of unfettered economic promotion occurred in May 2016, when the then Minister of Environment and Forests, Prakash Javadekar, stated his ministry granted environmental clearance (EC) to 2,000 projects in 190 days for ease of doing business. The minister stated environment clearances are given without compromising stringent pollution norms. ${ }^{190}$ However, evidence suggests that regulatory environmental laws and procedures were ignored or short-circuited in the race for economic returns. Errors include failure to provide mandatory documentation, inadequate stakeholder participation, and deliberate concealment or submission of false or misleading information for the EC process. A study by the Centre for

\footnotetext{
186. Narendra Modi (2018); also see Indian Express (2015). At the 2015 UN General Assembly Sustainable Development Summit, Prime Minister Modi stated "addressing the needs of 1.3 billion poor people in the world is not merely a question of their survival and dignity or our moral responsibility. It is a vital necessity for ensuring a peaceful, sustainable, and just world. Our attack on poverty today includes expanded conventional schemes of development, but we have also launched a new era of inclusion and empowerment, turning distant dreams into immediate possibilities .... We are focusing on the basics: housing, power, water and sanitation for all-important not just for welfare, but also human dignity .... We are making our farms more productive and better connected to markets; and, farmers less vulnerable to the whims of nature . . Nations have a national responsibility for sustainable development."

187. Ibid.; also see Modi (2015), wherein he argues for a low-carbon economy to achieve a clean and green India, thereby mitigating the menace of climate change and improving the environment. It should be based on a collective partnership between people, businesses, the scientific community, the government, and NGOs.

188. Financial Times (2018).

189. World Bank Report (2017), pp. 4, 7.

190. More (2016).
} 
Science and Environment, a Delhi-based research and advocacy organization, stated that, between June 2014 and April 2015, 103 mining projects and 54 infrastructure projects were granted ECs. The coal-mining sector was a special beneficiary, as projects were allowed in critically polluted areas via a diluted public-hearing requirement. ${ }^{191}$ The data showed that projects were being cleared and processes were made so convoluted that they stopped working to protect the environment. The report stated:

overall trend suggests that green clearances have been made faster through incremental changes "easing" the clearance process. However, there is no evidence that the quality of EIA reports has improved or enforcement on the ground have become more effective. ${ }^{192}$

In 2016, the Comptroller and Auditor-General of India published a Performance Audit on Environmental Clearance and Post Clearance Monitoring Report (CAG Report). ${ }^{193}$ Out of 216 projects that had been granted ECs between 2011 and July 2015, the report stated:

In 25\% cases, the Environment Impact Assessment reports did not comply with Terms of Reference and in $23 \%$ cases they did not comply with the generic structure of the report. Cumulative impact studies before preparing the Environment Impact Assessment reports were not made a mandatory requirement, thus the impact of a number of projects in a region on the ecosystem was not known. Ministry had not followed due process in issue of Office Memoranda and the Office Memoranda so issued had the effect of diluting the provisions of original notification. ${ }^{194}$

Environment regulations are being diluted to promote the ease of doing business and pursue an economic development model. The present government drafted controversial legislative proposals and took decisions that accommodate corporate interest and manipulate and subvert laws and safeguards that protect the rights of the tribal poor and the marginalized. These include the new National Forest Policy that allows the corporate sector to grow, harvest, and sell trees on government-owned forest lands, explicitly banned under the existing National Forest Policy $1988^{195}$; reducing tribal rights over forest land in favour of industries without securing the prior consent of Gram Sabha or village council ${ }^{196}$; allowing 16 new thermalpower plants in 2017 to come up in violation of the air-pollution norms. More than 300 old fossil-fuel-based power plants will also continue to violate pollution norms until at least 2020 with the government's approval. ${ }^{197}$

The NGT has consistently maintained its base position that it is not opposed to economic development. Nevertheless, it has been equally consistent that economic development is subject to the statutory rules and regulations passed to accommodate growth within the legal framework of sustainable development. The tribunal has been steadfast in its restraining decisions that identify processes that seek to fast-track development programmes by ignoring environmental protection rules. For example, in the Society for Protection of Environment and Biodiversity v. Union of India, ${ }^{198}$ the NGT quashed the December 2016 notification

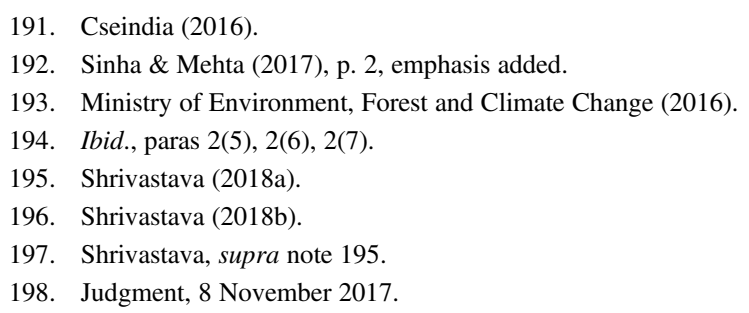


issued by the MoEF whereby substantive provisions of EIA Notification 2006 that require prior EC for building and construction activities were diluted. According to the NGT, the 2016 notification was ultra vires, as it permitted construction of buildings and apartments without complying with the environmental norms. The tribunal held that the magnitude of the environmental footprint would be immense and unregulated building and construction activity would cause considerable environmental damage. In a strongly worded judgment, the NGT observed:

The MoEF\&CC has failed to produce any study, literature, evaluation of the reason for taking such a retrograde decision .... The said amendment notification is only a ploy to circumvent the provisions of environmental assessment under the EIA Notification, 2006 in the name of "ease of doing responsible business" and there is no mechanism laid down under the amendment notification for evaluation, assessment or monitoring of the environment impact of the building and construction activity. The construction industry consumes enormous resources and has a significant energy footprint; the sector emits $22 \%$ of India's total annual carbon-dioxide emission .... The MoEF\&CC has failed to fulfil its statutory responsibilities. ${ }^{199}$

Similarly, in Paryawaran Sanrakshan Sangarsh Samiti Lippa v. Union of India, ${ }^{200}$ the NGT was left with a "deep sense of foreboding and serious anxiety on the future of the State and its progeny" 201 in the context of the proposed number of hydropower projects in the state of Himachal Pradesh and their subsequent ecological impacts. The NGT recognized the rights of villagers to be consulted concerning the construction of the Kashang Integrated Hydroelectric Project. ${ }^{202}$ The tribunal directed the MoEF and state government to ensure that, prior to the forest clearance for the project, the proposal is placed before a Gram Sabha of villages in the Kinnaur district of the state of Himachal Pradesh. ${ }^{203}$ The decision of the regulatory authorities failed to meet the statutory requirement to seek consent from forestdwelling tribals and other communities under the Forest Rights Act 2006.

These cases demonstrate that the Indian government and associated authorities failed to enforce the environment norms for the "ease of doing business." Further, India opposed the international guidelines that require free or uninfluenced consent of tribal communities for commercially using their traditional knowledge at the global biodiversity negotiations in Cancun, Mexico. ${ }^{204}$

The vulnerability felt by the MoEF as the result of the activity and willingness of the NGT to publicly criticize the ministry resulted in a practical response with the establishment by the MoEF of the High-Level Committee (HLC) in 2014 to review forest- and environmentrelated laws. T. S. R. Subramanium was appointed as the chairperson. ${ }^{205}$ Its terms of

199. Ibid., paras 17, 18, 23.

200. Judgment, 4 May 2016.

201. Ibid., para. 16 .

202. The construction of the 130-megawatt Kashang Integrated Hydro Electric Project involved the acquisition of forest land, thereby affecting the forest cover, valuable pine trees, and jeopardizing the livelihood of the community. See generally the Scheduled Tribes and Other Traditional Forest Dwellers (Recognition of Forest Rights) Act 2006 and condition 16 of the "In Principle" forest clearance.

203. See also Orissa Mining Corporation v. MoEF, 18 April 2013. The Supreme Court directed that the smallest units of local governance use their powers and take a decision on whether the Vedanta Group's USD 1.7 billion bauxitemining project in Odisha's Niyamgiri Hills should go forward. The decision validated the Gram Sabha's power under the Scheduled Tribes and Other Traditional Forest Dwellers (Recognition of Forest Rights) Act 2006.

204. Shrivastava (2016).

205. High-Level Committee on Forest and Environment Related Laws, supra note 185. 
reference were to assess the status and implementation of each of the key six Acts ${ }^{206}$ vis-à-vis the objectives, examining related various court orders and judicial pronouncements, and recommending and drafting proposed amendments to these Acts. Importantly, what was absent from the HLC's terms of reference was the authority to review the NGT Act. Nevertheless, the HLC exceeded its mandate and made recommendations that, if implemented, would have severely restricted the operational effectiveness of the NGT by the creation of extra decision-making institutional institutions: district environmental courts and an Appellate Board.

The HLC recommended the establishment of special environmental courts in every district and a new "umbrella" law - the Environmental Laws (Management) Act (ELMA). The ELMA provided for the creation of two institutions - the National Environmental Management Authority (NEMA) at central level and the State Environment Management Authority (SEMA) at state level-as full-time processing and EC and monitoring agencies. ${ }^{207}$ ELMA was also to be provided with an Appellate Board against the decisions of NEMA or SEMA or the MoEF in respect of project clearance, prescribing a three-month time limit for disposal of appeals. The decisions of the government, NEMA, or SEMA under this proposed law would not be questionable before nor enquired into by any court or tribunal either via suo moto or at anyone's behest on any ground. ${ }^{208}$ The jurisdiction of the NGT was to be limited to entertaining applications by parties aggrieved by the decisions in appeals under NEMA or SEMA for review on grounds permissible and subject to limitations applicable to judicial review of administrative actions by the High Courts and the Supreme Court of India. ${ }^{209}$

The HLC report was completed within three months and submitted to the government on 18 November 2014. It was subsequently considered by the Parliamentary Standing Committee on Science and Technology, Environment and Forests. The committee submitted its findings on 3 July 2015. The committee did not accept the HLC report because the period of three months allotted to the HLC for reviewing the six environmental Acts was considered too short and there was no cogent reason for rushing the report without comprehensive, meaningful, and wider consultations with all stakeholders. ${ }^{210}$ A careful reading of the text further suggests that the committee was supportive of the existing environmental judicial framework, particularly the NGT, and that it should not be disturbed. The Parliamentary Committee stated:

Some of the essential recommendations of the HLC have been doubted and would result in an unacceptable dilution of the existing legal and policy architecture established to protect our environment. Further, an impression should not be created that a Committee whose constitution and jurisdiction are itself in doubt, has been used to tinker with the established law and policy. Should the government wish to consider specific areas of environmental policy afresh, it may consider appointing another Committee by following established procedures and comprising of acclaimed experts. ${ }^{211}$

206. Environment (Protection) Act 1986, supra note 109; Forest (Conservation) Act 1980; Wildlife (Protection) Act 1972; Water (Prevention and Control of Pollution) Act 1974; Air (Prevention and Control of Pollution) Act 1981; and Indian Forest Act 1927.

207. High-Level Committee on Forest and Environment Related Laws, supra note 185, pp. 62, 63, 68-71.

208. Ibid., p. 75.

209. Ibid.

210. Parliamentary Standing Committee on Science and Technology, Environment and Forests (2015), p. 9.

211. Ibid. 
The amendment to the Finance Act 2017 is another recent effort to curb and dilute the powers of the NGT through legislative intervention. The Department of Revenue, Ministry of Finance vide notification dated 1 June 2017, in exercise of its powers under section 184 of the Finance Act 2017, notified the Tribunal, Appellate Tribunal and other Authorities (Qualifications, Experience and other Conditions of Service of Members) Rules, 2017 (new rules). The new rules give unbridled power to the central government to provide for the appointment, term of office, salaries and allowances, registration, removal, and other terms and conditions of service of the chairpersons and members of the tribunal including the NGT. For instance, the new rules have altered the terms of the NGT Act 2010 by allowing a nonjudicial member to be the chairperson of the tribunal. Section 5 of the NGT Act 2010 states that the chairperson of the NGT must have been a judge of the Supreme Court or a Chief Justice of a High Court. As per the new rules, a person can be appointed as a chairperson of the NGT if he is, or has been, or is qualified to be a judge of Supreme Court; or is, or has been, Chief Justice of a High Court; or has, for a period of not less than three years, held office as a judicial or expert member or is a person of ability, integrity, and standing, and having special knowledge of, and professional experience of, not less than 25 years in law, including five years of practical experience in the field of environment and forests. The qualifications to become an expert or judicial member at the NGT are also diluted, while giving greater bureaucratic control over the selection procedure. $^{212}$

These new rules are designed to create systemic changes that undermine the system of institutional checks and balances and potentially create a conflict of interests. In Union of India v. R. Gandhi, ${ }^{213}$ the Supreme Court held:

Impartiality, independence, fairness and reasonableness in decision making are the hallmarks of Judiciary. If "Impartiality" is the soul of Judiciary, "Independence" is the life blood of Judiciary. Without independence, impartiality cannot thrive. Independence is not the freedom for Judges to do what they like. It is the independence of judicial thought. It is the freedom from interference and pressures which provides the judicial atmosphere where he can work with absolute commitment to the cause of justice and constitutional values .... If Tribunals are to be vested with judicial power hitherto vested in or exercised by courts, such Tribunals should possess the independence, security and capacity associated with courts. ${ }^{214}$

The new rules invited criticism from green activists, who called the provisions "draconian" and "the death knell for NGT and all other Tribunals in the country" and stated:

The new qualifications have serious consequences and huge implications for the quality of leadership as well as independence of the NGT ... the NGT will not have the administrative as well as functional autonomy and will be "under" the control of the very Ministry [MoEF] whose decisions they are required to adjudicate upon. ${ }^{215}$

The changes threaten to cripple the independence of the NGT. The new rules were challenged in the Supreme Court by former environment minister Jairam Ramesh because they violate the doctrine of separation of powers and suffer from issues of excessive delegation to

\footnotetext{
212. Dutta (2017).

213. (2010) 6 S.C.R 857.

214. Ibid., pp. 907-8.

215. Aggarwal (2017); Dutta, supra note 212; Venkatasubramanian (2017).
} 
the central government. ${ }^{216}$ Consequently, the Supreme Court in February 2018 stayed the provisions of the Finance Act 2017 that amended the rules of appointment to the tribunals, including the NGT. The court directed that the "terms and conditions of service of members of the National Green Tribunal shall be governed by the provisions of the National Green Tribunal Act, 2010." ${ }^{217}$ The interim stay order by the Supreme Court protected the NGT, as it ensures that the appointment and selection process to the NGT remains free from executive influence and ensures parliamentary scrutiny.

In addition, the recent development of non-filling bench membership, reluctance to authorize appropriate staff, infrastructure, and resource support by the MoEF bears testimony to the fact that the government wants to restrict the activities of the NGT. Seventy percent of the bench positions are currently vacant. ${ }^{218}$ This is a systematic way of dismantling the institution. The NGT Act 2010 states that the minimum number of full-time judicial and expert members will not be less than ten, with a maximum of 20. At present, the NGT has five bench members (three judicial and two technical experts) for the principal bench in Delhi. On 28 March 2018, the Supreme Court appointed Justice Jawad Rahim as the Acting Chairperson of the NGT because of the petition filed by the NGT Bar Association. ${ }^{219}$ The regional benches (Bhopal, Chennai, Pune and Kolkata) have no bench members and thus are dormant. The Supreme Court sought an explanation from the central government about the non-filling of vacancies in the NGT. Shocked by the crisis, the Delhi High Court recently asked the centre whether it "planned to wind up the NGT?"220 Instead of filling the vacant positions, the MoEF on 1 December 2017 issued a notification empowering the NGT chairperson to constitute single-member benches. ${ }^{221}$ The Supreme Court, as a driving force, on 31 January 2018, held the ministry's notification approving the constitution of NGT single-judge benches to be ultra vires the NGT Act $2010 .^{222}$

Nevertheless, there is evidence of strong "restraining forces" seeking to destabilize the NGT, as illustrated in Figure 8.

Currently, there exists a turf war between various interests and institutions (NGT, MoEF, associated regulatory authorities) involved in environmental regulation and environmental jurisprudence. The refreezing stage is witnessing the "restraining forces" outweighing the "driving forces." As presented by Lewin and Schein, the equilibrium is lost and the NGT's power and effectiveness are being challenged by the oppositional, negative force field. Consequently, unfreezing of the NGT has commenced.

216. Livemint (2017).

217. Basu (2018).

218. Sahu (2018). Justice Swatanter Kumar, the dynamic Chairperson NGT, retired on 19 December 2017; he was succeeded by acting Chairperson Justice U. D. Salvi, who retired on 13 February 2018. The Chennai bench became inoperative from 3 January 2018. No judgment has been passed by the Kolkata bench since 16 November 2016. The Pune bench has not had an expert member since the retirement of Dr Ajay Deshpande in May 2017.

219. Indian Express (2018a).

220. Nair (2017).

221. Amendment to the National Green Tribunal (Practices and Procedure) Rules, 2011, which states that, in exceptional circumstances, the chairperson may constitute a single-member bench. See Ashok (2017).

222. Indian Express (2018b). 


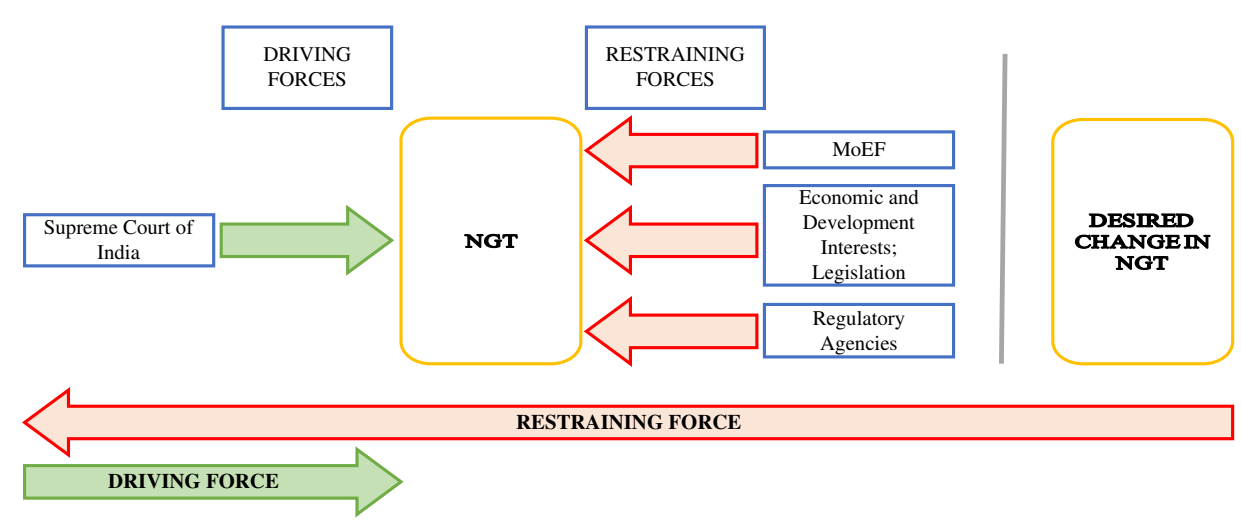

Figure 8. Current dominant restraining forces. Source: Author

\section{CONCLUSION}

Lewin believed that there is nothing so practical as a good theory. ${ }^{223}$ This article has laid out Lewin's organizational change theory as supported and enhanced by Schein. Thereafter, it is applied chronologically to the establishment and growth of the NGT. By identifying the reasons and actions of the principal actors and interests involved in the dynamic rise and decline of the tribunal, there emerges a holistic explanation that provides a further example of the insightfulness of Lewin's work. Simply offering a record of events without investigating and analyzing the story behind the happening is misleading and would reflect a doctrinal approach unsuitable for the pages of this Journal.

Speaking truth to power can be perilous, as the NGT judges, chairman, lawyers, and litigants have discovered. The creation of a tribunal that seeks to change the face of environmental jurisprudence by providing access to justice for all has created a powerful group of "restraining forces." The MoEF, state governments, and various environmental statutory bodies and their officers are unaccustomed to being questioned in a probing, informed, and systematic manner or have their decisions scathingly challenged or overturned in a public forum. Previously, these authorities enjoyed both an official and an unofficial decisionmaking licence power directly associated with various expert committees, boards, and officials, as well as the minister. The result was often arbitrary approval of projects without undertaking the proper environmental and social-impact assessments and disturbingly often in violation of pertinent laws and rules. Additionally, some High Courts along with the MoEF went so far as to challenge the authority of the tribunal to exercise suo moto and judicial review powers. The tribunal's constant position of decisions based on the principle of sustainable development and the enforcement of the rules upholding the protection of the environment has proven to be embarrassing to those committed to a fast-track economic development strategy.

History can be repetitious. The demise of the NEAA offers a salutary case lesson. ${ }^{224}$ Constituted by statute in 1997, albeit with limited powers, the government failed to fill the vacancies of chair and deputy chairpersons between 2000 and 2010, stating an inability to

223. Lewin, supra note 32, p. 421.

224. Vimal Bhai v. Union of India High Court of Delhi, supra note 83; NGT Act 2010, supra note 84. 
identify suitably qualified people. The Act was repealed by the NGT Act 2010. Given the current and alarming number of vacancies on the NGT benches resulting in the de facto operational closure of the regional benches, could there be a similar fate planned for the NGT: death by 1000 cuts?

Today, the NGT stands at a crossroads. Without the replacement of qualified bench members and the formal renewal of support from key actors who constitute the "restraining forces," the tribunal may fall into the Thucydides trap: a victim of its own success.

\section{REFERENCES}

Aggarwal, Mayank (2014) "NGT Flays Government for Ambiguity over Safety of Western Ghats," http://www.dnaindia.com/india/report-ngt-flays-government-for-ambiguity-over-safety-of-western-ghats-2013665 (accessed 17 December 2017).

Aggarwal, Mayank (2017) “Green Activists Oppose Finance Act 2017, Say It Curtails NGT's Independence," https://www.livemint.com/Politics/X4R0eZMQ5R6i5SlW0oGjoL/Green-activistsoppose-Finance-Act-2017-say-it-curtails-NGT.html (accessed 12 February 2018).

Ahmady, G. A., M. Mehrpour, \& A. Nikooravesh (2016) "Organizational Structure.” 230 Procedia: Social and Behavioural Sciences 455-62.

Allen, Jennifer M., \& Rajeev Sawhney (2018) Administration and Management in Criminal Justice: A Service Quality Approach, Thousand Oaks, CA: SAGE Publications.

Anand, Utkarsh (2013) "SC Fumes as MoEF Says NGT Causing Govt Embarrassment," http://archive. indianexpress.com/news/sc-fumes-as-moef-says-ngt-causing-govt-embarrassment/1168479/ (accessed 16 September 2017).

Ashok, Sowmiya (2017) "Centre Passes Notification, Allows NGT to Form One-member Benches," $\mathrm{http}$ ://indianexpress.com/article/india/centre-passes-notification-allows-ngt-to-form-one-memberbenches-4968206/ (accessed 7 January 2018).

Asian Development Bank (2012) "Environmental Governance and the Courts in Asia," Brief 1, Law and Policy Reform.

Asian Development Bank (2015) "Fourth ASEAN Chief Justices' Roundtable on Environment: Role of the Judiciary in Environmental Protection," Roundtable Proceedings: Asian Development Bank.

Balogun, Julia, \& V. H. Hailey (2004) Exploring Strategic Change, London: Prentice Hall.

Barzelay, M. (2002) "Origins of the New Public Management: An International View from Public Administration/Political Science," in K. McLaughlin, S. P. Osborne \& E. Ferlie, eds., New Public Management: Current Trends and Future Prospects, London: Routledge, 15-33.

Basu, Jayanta (2018) "SC Breather for Green Tribunals," https://www.telegraphindia.com/india/scbreather-for-green-tribunals-207982 (accessed 22 April 2018).

Baulcomb, J. S. (2003) "Management of Change through Force Field Analysis." 11 Journal of Nursing Management 275-80.

BBC (2016) "India Environment Watchdog Anger over Ganges Pollution,” http://www.bbc.co.uk/ news/world-asia-india-35359089 (accessed 20 November 2017).

Bhurban Declaration (2012) "A Common Vision on Environment for the South Asian Judiciaries," http://cmsdata.iucn.org/downloads/pk_bhurban_declaration_2012_20120410_.pdf (accessed 14 September 2017).

Bozak, Marylin G. (2003) "Using Lewin's Force Field Analysis in Implementing a Nursing Information System.” 21 CIM: Computers, Informatics, Nursing 80-5.

Brunsson, Nils (1989) The Organization of Hypocrisy: Talk, Decision and Actions in Organizations, Chichester: John Wiley \& Sons.

Burnes, Bernad (2004) "Kurt Lewin and the Planned Approach to Change: A Re-appraisal." 41 Journal of Management Studies 977-1002. 
Burnes, Bernard (2009) Managing Change: A Strategic Approach to Organisational Dynamics, Harlow: Prentice Hall.

Burnes, Bernad, \& B. Cooke (2013) "Kurt Lewin's Field Theory: A Review and Re-evaluation.” 15 International Journal of Management Reviews 408-25.

By, R. Todnem (2005) "Organisational Change Management: A Critical Review." 5 Journal of Change Management 369-80.

Carnall, Colin A. (2003) Managing Change in Organizations, Harlow: Prentice Hall.

Carnwath, L. Robert (2017) "Judging the Environment-Back to Basics." 29 Environmental Law and Management 64-71.

Cartwright, Dorwin (1952) "Foreword," in D. Cartwright, ed., Field Theory in Social Science: Selected Theoretical Papers by Kurt Lewin, London: Social Science Paperbacks, vii-Xv.

Child, John (2005) Organization: Contemporary Principles and Practice, Oxford: Blackwell.

Chowdhary, Yukti (2014) "Tribunal on Trial," http://www.downtoearth.org.in/coverage/tribunal-ontrial-47400 (accessed 11 October 2016).

Christensen, Tom, Per Laegrid, Paul G. Roness, \& Kjell Arne Rovik (2008) Organization Theory and the Public Sector: Instrument, Culture and Myth, London: Routledge.

Clegg, Stewart R., M. Kornberger, \& T. Pitsis (2005) Managing and Organisations: An Introduction to Theory and Practice, London: SAGE.

Cseindia (2016) "NDA's Environmental Clearance Record Not Significantly Different from UPAs' Centre for Science and Environment," http://www.cseindia.org/content/ nda\%E2\%80\%99s-environmental-clearance-record-not-signi cantly-different-upa\%E2 \%80\%99s-says-analysis-cse (accessed 10 December 2017).

Cummings, Stephen, T. Bridgman, \& Brown Kenneth G. (2016) "Unfreezing Change as Three Steps: Rethinking Kurt Lewin's Legacy for Change Management." 69 Human Relations 33-60.

Desai, Bharat H., \& Balraj Sandhu (2010) "On the Quest for Green Courts in India." 3 Journal of Court Innovation 79-110.

Domas, M. Hantke (2017) "Book Review—Environmental Justice in India: The National Green Tribunal." 6 Transnational Environmental Law 557-60.

Downtoearth.org (2014) "The NGT Must Have Suo Motu Powers," http://www.downtoearth.org.in/ interviews/ngt-must-have-suo-motu-powers-47542 (accessed 15 July 2016).

Dutta, Ritwick (2015) "India's Green Tribunal Takes on Major Environmental Abuses," https://elaw. org/indias-green-tribunal-takes-major-environmental-abuses (accessed 10 June 2016).

Dutta, Ritwick (2017) "How the Finance Act 2017 Cripples National Green Tribunal (NGT)," http:// www.livelaw.in/finance-act-2017-cripples-national-green-tribunalngt/ (accessed 10 January 2018).

Economictimes.indiatimes (2017a) "NGT Raps MoEF Over Emission Standards for Thermal Power Plants," https://economictimes.indiatimes.com/news/politics-and-nation/ngt-raps-moef-over-emission-standards-for-thermal-power-plants/articleshow/60813505.cms (accessed 21 February 2018).

Economictimes.indiatimes (2017b) "Why Contempt Should Not Be Initiated Against Delhi Govt, DJB: NGT," https://economictimes.indiatimes.com/news/politics-and-nation/why-contempt-should-notbe-initiated-agnst-delhi-govt-djb-ngt/articleshow/61185784.cms (accessed 13 January 2018).

Faure, Michael G., \& A. V. Raja (2010) "Effectiveness of Environmental Public Interest Litigation in India: Determining the Key Variable.” 21 Fordham Environmental LR 239-92.

Financial Times (2018) Narendra Modi Aims to Double the Size of Indian Economy by 2025," https:// www.ft.com/content/156e5e7e-0047-11e8-9650-9c0ad2d7c5b5 (accessed 20 April 2018).

Galanter, Marc (2014) "Snakes and Ladders: Suo Motu Intervention and the Indian Judiciary." 10 FIU Law Review 69-83.

Ghosal, Anniruddha (2014) "Western Ghats: NGT Rap for Forest Ministry," http://indianexpress.com/ article/india/india-others/western-ghats-ngt-rap-for-forest-ministry/ (accessed 6 April 2016).

Gill, G. Nain (2012) "Human Rights and the Environment in India: Access through Public Interest Litigation." 14 Environmental Law Review 200-18.

Gill, G. Nain (2015) "Human Rights and Environmental Protection in India: A Judicial Journey from Public Interest Litigation to the National Green Tribunal," in A. Grear \& E. Grant, eds., Thought, Law, Rights and Action in an Age of Environmental Crisis, UK: Edward Elgar, 123-54. 
Gill, G. Nain (2016) "Environmental Justice in India: The National Green Tribunal and Expert Members." 5 Transnational Environmental Law 175-205.

Gill, G. Nain (2017) Environmental Justice in India: The National Green Tribunal, Abingdon, Oxon: Routledge.

Gogoi, Rajan (2017) "Message-International Conference on Environment." 2 National Green Tribunal International Journal on Environment 21.

Graetz, Fiona (2000) "Strategic Change Leadership." 38 Management Decision 550-62.

Gulati, Ranjay (2007) "Tent Poles, Tribalism, and Boundary Spanning: The Rigor-Relevance Debate in Management Research." 50 Academy of Management Journal 775-82.

Hammer, Michael, \& J. Champy (1993) Reengineering the Corporation: A Manifesto for Business Revolution, New York: HarperBusiness.

High-Level Committee on Forest and Environment Related Laws (2014) Report MoEF \& CC, http:// envfor.nic.in/sites/default/files/press-releases/Final_Report_of_HLC.pdf (accessed 19 February 2015).

Hindustan Times (2017) "Delhi Air Pollution: NGT Pulls Up AAP Govt for Not Filing Action Plan, Holding India-Sri Lanka Test," https://www.hindustantimes.com/delhi-news/delhi-air-pollutionngt-slams-authorities-for-holding-india-sri-lanka-test-amid-bad-air-quality/story-PUKWlesX2eh3 hRZNSHzLyL.html (accessed 7 January 2018).

Hussain, S. Talib, Shen Lei, Tayyaba Akram, Muhammad Jamal Haider, Syed Hadi Hussain, \& Muhammad Ali. (2017) "Kurt Lewin's Change Model: A Critical Review of the Role of Leadership and Employee Involvement in Organizational Change." 26 Journal of Innovation and Knowledge $1-7$.

Hustedde, Ron, \& M. Score (1995) "Force-field Analysis: Incorporating Critical Thinking in Goal Setting." 4 CD Practice 1-6.

Indian Express (2015) "Full Text: PM Modi's Address at United Nations Sustainable Development Summit," http://indianexpress.com/article/world/world-news/full-text-pm-modis-address-to-theunited-nations-general-assembly/ (accessed 10 March 2016).

Indian Express (2018a) "Justice Rahim Appointed Acting Chairperson of NGT," http://indianexpress. com/article/india/justice-rahim-appointed-acting-chairperson-of-ngt-5113810/ (accessed 30 April 2018).

Indian Express (2018b) "No Single Judge Bench Can Hear Cases at NGT: Supreme Court," http:// indianexpress.com/article/india/no-single-judge-bench-can-hear-cases-at-ngt-supreme-court5046408/ (accessed 28 April 2018).

iucn.org (2018) "WCEL and GJIE: Tribute to Justice Swatanter Kumar and India's National Green Tribunal," https://www.iucn.org/news/world-commission-environmental-law/201802/wcel-andgjie-tribute-justice-swatanter-kumar-and-india\%E2\%80\%99s-national-green-tribunal (accessed 15 March 2018).

Ivanko, Štefan (2013) Modern Theory of Organisation, Ljubljana: University of Ljubljana Faculty of Public Administration.

Javadekar, Prakash (2017) "Message_International Conference on Environment." 2 National Green Tribunal International Journal on Environment 17.

Johannesburg Principles (2002) "The Johannesburg Principles on the Role of Law and Sustainable Development," adopted at the Global Judges Symposium in Johannesburg https://www.eufje.org/ images/DocDivers/Johannesburg\%20Principles.pdf (accessed 17 May 2014).

Kanter, Rosabeth M., Barry A. Stein, \& Todd D. Jick (1992) The Challenge of Organizational Change, New York: Free Press.

Kippenberger, T. (1998) "Planned Change: Kurt Lewin's Legacy.” 3 The Antidote 10-12.

Kotter, John P. (2007) "Leading Change: Why Transformation Efforts Fail." 86 Harvard Business Review 97-103.

Lan, L. Luh, \& Jean Lee (1997) "Force-field Analysis on Policies Affecting Working Women in Singapore." 16 Journal of Management Development 43-52.

Law Commission of India (2003) "Proposal to Constitute Environment Courts 186th Report," http:// lawcommissionofindia.nic.in/reports/186th\%20report.pdf (accessed 9 September 2014).

Law Commission of India (2017) "Assessment of Statutory Frameworks of Tribunals in India 272nd Report," http://lawcommissionofindia.nic.in/reports/Report272.pdf (accessed 10 February 2018). 
Legal India (2012) “SC Slams Poor Facilities for Green Tribunal,' https://www.legalindia.com/news/ sc-slams-poor-facilities-for-green-tribunal (accessed 24 November 2013).

Lenin, Janaki (2011) "Green Fundamentalism Will Not Work Says Jairam Ramesh," https://www. firstpost.com/blogs/green-fundamentalism-will-not-work-says-jairam-ramesh-42646.html (accessed 20 May 2014).

Lewin, Kurt (1943) "Psychological Ecology," in Dorwin Cartwright, ed., Field Theory in Social Science, London: Social Science Paperbacks, 170-87.

Lewin, Kurt (1947) "Frontiers in Group Dynamics," in Dorwin Cartwright, ed., (1952) Field Theory in Social Science: Selected Theoretical Papers by Kurt Lewin, London: Social Science Paperbacks, 188-237.

Lewin, Kurt (1997) Resolving Social Conflicts and Field Theory in Social Science, Washington: American Psychological Association.

Livemint (2017) "Jairam Ramesh Moves SC Against Diluting of Rules on Appointments to Tribunals, Including NGT," http://www.livelaw.in/jairam-ramesh-moves-sc-diluting-rules-appointments-tribunals-including-ngt-read-petition/ (accessed 12 March 2018).

London Bridge Statement (2002) "IUCN-The World Conservation Union, IUCN Commission on Environmental Law: Symposium on Environmental Law for European Judges," http://weavingaweb.org/pdfdocuments/ London Bridge Statement.pdf (accessed 18 August 2015).

Luecke, Richard (2003) Managing Change and Transition, Boston, MA: Harvard Business School Press.

Lynn Jr, Laurence E. (1998) "The New Public Management: How to Transform a Theme into a Legacy." 58 Public Administration Review 231-7.

Mahapatra, Dhananjay (2013) "Kolkata May Lose Green Tribunal Bench to Guwahati or Ranchi," https://timesofindia.indiatimes.com/city/kolkata/Kolkata-may-lose-green-tribunal-bench-to-Guwahati-or-Ranchi/articleshow/20996616.cms (accessed 25 November 2015).

Mak, Elaine (2008) "The European Judicial Organisation in a New Paradigm: The Influence of Principles of 'New Public Management' on the Organisation of the European Courts." 14 European Law Journal 718-34.

Marshak, R. J., \& L. Heracleous (2004) "Organizational Development," in S. Clegg \& J. Bailey, eds., International Encyclopaedia of Organization Studies, Thousand Oaks, CA: SAGE, $1047-52$.

Mayabushan (2013) "NGT Ban Judicial Overreach," http://www.dailypioneer.com/nation/ngt-banjudicial-overreach.html (accessed 4 March 2018).

Milton, John (1667) Paradise Lost Book 1: Longman's English Classics, Harvard University, USA: Longmans, Green \& Company, L., 105.

Ministry of Environment, Forest and Climate Change (2016) "The Comptroller \& Auditor General of India Performance Audit Report on Environmental Clearance and Post Clearance (Number 39 of 2016)," https://www.cag.gov.in/sites/default/files/audit_report_files/Union_Government_Report_ 39_of_2016_PA.pdf (accessed 12 February 2018).

Modi, Narendra (2015) Convenient Action-Continuity for Change, Gurgaon: Lexis Nexis.

Moog, Robert (1992) "Delays in the Indian Courts: Why the Judges Don't Take Control." 16 Justice System Journal 19-36.

Moran, John W., \& B. K. Brightman (2001) "Leading Organizational Change.” 6 Career Development International 111-18.

More, M. Dattatrye (2016) "Green Project Clearances Now in 190 Days Not in 600 Days: Prakash Javadekar," http://indianexpress.com/article/india/india-news-india/green-project-clearances-nowin-190-days-not-in-600-days-javadekar-2813341/ (accessed 19 November 2017).

Naidu, M. Venkaiah (2017) "Message —International Conference on Environment." 2 National Green Tribunal International Journal on Environment 9.

Nair, Harish V. (2017) "Supreme Court Seeks Explanation from Centre on Acute Shortage of Judges in NGT," https://www.indiatoday.in/mail-today/story/ngt-judges-vacancy-supreme-court-centreappoint-judges-1099148-2017-12-03 (accessed 10 February 2018). 
Narendra Modi (2018) "PM Modi Addresses World Sustainable Development Summit," https://www. narendramodi.in/pm-modi-addresses-world-sustainable-development-summit-538963 (accessed 5 June 2018).

Ng, G. Yein (2007) Quality of Judicial Organisation and Checks and Balances, Antwerp: Intersentia.

Padma, TV (2011) "Jairam Ramesh's Legacy Is an Indian Environment Ministry with an Identity," https://www.theguardian.com/environment/blog/2011/jul/13/jairam-ramesh-india-environmentministry (accessed 14 February 2014).

Parliament of India (Rajya Sabha) Department-related Parliamentary Standing Committee on Science and Technology, Environment and Forests (2015) Two Hundred Sixty Third Report, available at http://164.100.47.5/newcommittee/reports/EnglishCommittees/Committee\%20on\%20S\%20and\% 20T,\%20Env.\%20and\%20Forests/263.pdf (accessed 12 March 218).

Petrick, Joe, \& William Lindsay (1996) Total Quality and Organization Development, St. Lucie Press Total Quality Series, UK: CRC Press.

Pierce, J. L., D. G. Gardner, \& R. B. Dunham (2002) "Management Organizational Change and Development," in J. L. Pierce, D. G. Gardner \& R. B. Dunham, eds., Management and Organizational Behaviour: An Integrated Perspective, Cincinnati, OH: South-Western College Publishing, 627-57.

PLA Notes (Participatory Learning and Action) (1999) International Institute of Environment and Development, London, UK, 17-23.

Polanki, Pallavi (2014) "National Green Tribunal Assets Independence, Is Environment Minister Listening?," https://www.firstpost.com/india/national-green-tribunal-asserts-independence-environment-minister-listening-1625527.html (accessed 22 August 2016).

Pollitt, Christopher (1995) "Justification by Faith or by Works? Evaluating the New Public Management." 1 Evaluation 133-54.

Preston, Brian J. (2012) "Benefits of Judicial Specialisation in Environmental Law: The Land and Environment Court of New South Wales as a Case Study." 29 Pace Environmental 395-440.

Pring, George, \& Catherin Pring (2016) The ABCs of the ECTs: A Guide for Policy Makers for Designing and Operating a Specialised Environmental Court or Tribunal, Nairobi: United Nations Environment Programme.

Prsindia.org (2009) "The National Green Tribunal Bill 2009," http://www.prsindia.org/billtrack/thenational-green-tribunal-bill-2009-740/ (accessed 20 May 2011).

Rackemann, Michael (2017) "Book Review-Environmental Justice in India—The National Green Tribunal." 45 Denver Journal of International Law \& Policy 471-5.

Rajamani, Lavanya (2007) "Public Interest Litigation in India: Exploring Issues of Access, Participation, Equity, Effectiveness and Sustainability." 19 Journal of Environmental Law 293-321.

Rediff (2011) "What Jairam Did and Didn't Do as Green Minister," http://www.rediff.com/news/ column/what-jairam-ramesh-did-and-did-not-do-as-green-minister/20110720.htm (accessed 28 October 2013).

Rediff (2013) "When Tribunals Undermine the Judiciary," http://www.rediff.com/news/column/whentribunals-undermine-the-judiciary/20131025.htm (accessed 10 March 2015).

Rome Symposium (2003) "IUCN Commission on Environmental Law Judiciary Specialist GroupActivities Report 2003," http://weavingaweb.org/28-43.html (accessed 21 September 2014).

Rummel, Rudolph J. (1975) Understanding Conflict and War, Volume 1: The Dynamic Psychological Field, New York: Halsted Press.

Ryall, Aine (2017) "Book Review-Environmental Justice in India-The National Green Tribunal.” 1 Irish Planning and Environmental Law Journal 3-6.

Sahu, Geetonjoy (2008) "Implication of Indian Supreme Courts Innovation for Environmental Jurisprudence." 4 Law, Environmental and Development Journal 377-93.

Sahu, Geetonjoy (2018) "Ecocide by Design? Under Modi, Vacancies at the National Green Tribunal Reach 70\%," https://thewire.in/223978/ngt-political-apathy-vacancies/ (accessed 27 April 2018).

Schein, Edgar H. (1988) Organisational Psychology, London: Prentice Hall.

Schein, Edgar H. (2010) Organisational Culture and Leadership, San Francisco: Jossey-Bass. 
Shrivastava, K. L., \& P. K. Shrivastava (2015) Frontiers of Earth Science- A Festschriffor Dr Harish Kumar Gupta, Jodhpur: Scientific Publishers.

Shrivastava, K. Sambhav (2012) "Green Tribunal Gets Short Shrift," http://www.downtoearth.org.in/ news/green-tribunal-gets-short-shrift-38426 (accessed 4 November 2015).

Shrivastava, K. Sambhav (2016) "India, Others Get UN Rules on Tribal Rights Diluted," https://www. hindustantimes.com/india-news/india-others-get-un-rules-on-tribal-rights-diluted/story-xtD82yGjIeEAo4jV8y7QZI.html (accessed 15 March 2017).

Shrivastava, K. Sambhav (2018a) "Centre Seeks to Change Forest Policy to Promote Industrial Plantations in Natural Forests," https://scroll.in/article/872579/centre-seeks-to-change-forest-policy-topromote-industrial-plantations-in-natural-forests (accessed 15 April 2018).

Shrivastava, K. Sambhav (2018b) "India Allows 16 New Thermal Power Plants that Violate Stricter Air Pollution Standards to Come Up," https://scroll.in/article/852288/india-allows-16-new-thermalpower-plants-that-violate-stricter-air-pollution-standards-to-come-up (accessed 15 April 2018).

Sinha, Debadityo, \& Dhvani Mehta (2017) "Environmental Clearances and Monitoring in India: Report Card for the Ministry for Environment, Forest and Climate Change." Vidhi Centre for Policy Change 1-34.

Subramani, A. (2014) "Green Tribunal's Wings Clipped, Madras High Court Halts Suo Motu Proceedings," https://timesofindia.indiatimes.com/city/chennai/Green-tribunals-wings-clipped-Madrashigh-court-halts-suo-motu-proceedings/articleshow/28346066.cms (accessed 18 October 2014).

Swachhindia (2017) "Punjab and Haryana State Governments Criticised by National Green Tribunal For Filing Generalised Action Plans To Tackle Air Pollution," http://swachhindia.ndtv.com/punjaband-haryana-state-governments-criticised-by-national-green-tribunal-for-filing-generalised-actionplans-to-tackle-air-pollution-15596/ (accessed 12 February 2018).

Tsoukas, Haridimos, \& Robert Chia (2002) “On Organizational Becoming: Rethinking Organizational Change." 13 Organizational Science 567-82.

United Nations Development Programme (2014) "Environmental Justice: Comparative Experiences in Legal Empowerment," http://www.undp.org/content/undp/en/home/librarypage/democratic-governance/access_to_justiceandruleoflaw/environmental-justice_comparative-experiences.html (accessed 5 August 2016).

United Nations Environment Programme (2005) "Global Judges Programme," https://www.doe.ir/ portal/file/?116502/Unep-Global-Judges-programme.pdf (accessed 21 July 2014).

United Nations Environment Programme (2015) "Putting Rio Principle 10 into Action: An Implementation Guide for the UNEP Bali Guidelines for the Development of National Legislation on Access to Information, Public Information and Access to Justice in Environmental Matters," https:// wedocs.unep.org/bitstream/handle/20.500.11822/11201/UNEP\%20MGSB-SGBS\%20BALI\% 20GUIDELINES-Interactive.pdf?sequence $=1 \&$ isAllowed $=y$ (accessed 30 November 2016).

Van d. Walle, Steven, \& G. Hammerschmid (2011) "The Impact of the New Public Management: Challenges for Coordination and Cohesion in European Public Sectors." 12 HalduskultuurAdministrative Culture 190-209.

Venkatasubramanian (2017) "Finance Act Amendment: Tightening the Noose," http://www.indialegallive.com/constitutional-law-news/acts-and-bills-news/finance-act-amendment-tightening-thenoose-30732 (accessed 23 April 2018).

Warnock, Ceri (2017) "Book Review-Environmental Justice in India-The National Green Tribunal." 20 Asia Pacific Journal of Environmental Law 209-12.

World Bank Report (2017) "Doing Business 2018: Reforming to Create Jobs," http://www.doingbusiness.org/ /media/WBG/DoingBusiness/Documents/Annual-Reports/English/DB2018-FullReport.pdf (accessed 15 March 2018). 